\title{
Abstention by Federal Courts in Suits Challenging State Administrative Decisions: The Scope of the Burford Doctrine
}

Since the early 1940s, the Supreme Court has developed several doctrines under which a federal court may abstain from exercising its jurisdiction, leaving the parties to proceed in state court. ${ }^{1}$ The abstention doctrines thus provide judicial exceptions to the federal jurisdictional statutes in order to prevent federal courts from intruding unnecessarily into matters of importance to the states." The "administrative abstention" doctrine, created by the Supreme Court in Burford v. Sun Oil Co., allows federal courts to abstain from reviewing certain decisions of state administrative agencies or from otherwise assuming the functions of state courts in the development and implementation of a state's public policies. Despite thirty-six years of case law, the contours of Burford abstention remain unclear.

This comment examines the rationale and development of the Burford doctrine and suggests ways in which that doctrine should

1 Three major categories of abstention are Burford abstention, on which this comment focuses; Pullman abstention, discussed in text and notes at notes 11-16, 111-112, 121-122 infra; and Thibodaux abstention, discussed in note 43 and text and notes at notes 113, 121122 infra. Another important form of abstention, not discussed in this comment, is the doctrine of equitable restraint in cases seeking injunctions against criminal prosecution for violations of allegedly unconstitutional state laws. See Younger v. Harris, 401 U.S. 37 (1971); Dombrowski v. Pfister, 380 U.S. 479 (1965); Douglas v. City of Jeannette, 319 U.S. 157 (1943). See generally Laycock, Federal Interference with State Prosecutions: The Need for Prospective Relief, 1977 Sup. CT. REv. 193.

For a canvassing of these and other abstention doctrines, see Colorado River Water Conservation Dist. v. United States, 424 U.S. 800, 813-17 (1976). See generally P. BatoR, P. Mishkin, D. Shapiro \& H. Wechsler, Hart \& Wechsler's The Federal Courts and the Federal System 985-1009 (2d ed. 1973) [hereinafter cited as Hart \& Wechsler]; D. CuRrie, Federal. Courts 657-68 (2d ed. 1975); 3 K. Davis, Administrative Law Treatisf: $\S 23.18$ (1958); 1A J. Moore, Federal Practice If 0.203[1]-[2] (2d ed. 1979); 17 C. Wright, A. Miller \& E. Cooper, Federal Practice \& Procedure \$§ $4241-4248$ (1978); Comment, Contraction of Federal Jurisdiction: Convenience or Necessity?, 19 U. CHI. L. REv. 361 (1952).

2 Thus, abstention allows federal courts to avoid having to decide every case properly brought within a statutory grant of jurisdiction. Prior to the development of the abstention doctrines, federal jurisdiction was viewed differently: "It is most true, that this court will not take jurisdiction if it should not: but it is equally true, that it must take jurisdiction, if it should. The judiciary cannot, as the legislature may, avoid a measure, because it approaches the confines of the constitution." Cohens v. Virginia, 19 U.S. (6 Wheat.) 264, 404 (1821) (Marshall, C.J.). Accord, Bacon v. Rutland R.R., 232 U.S. 134, 137 (1914); Prentis v. Atlantic Coast Line Co., 211 U.S. 210, 228 (1908); Ex parte Young, 209 U.S. 123, 143 (1908) (quoting Cohens, 19 U.S. (6 Wheat.) at 404).

319 U.S. 315 (1943). 
be reformulated. Study of the Burford case law, and of the policies underlying the doctrine, indicates that the abstention decision should be based on two considerations only: the benefit that a litigant would derive from having his case heard in the federal forum, and the harm that federal intervention would do to state interests. A court is justified in abstaining only when the harm to the state outweighs the benefit to the litigant. Judged in the light of this equitable balance, many of the considerations that have led courts to abstain are insufficient. The comment concludes that abstention under the Burford doctrine is appropriate only in a special class of cases in which adjudication by a federal court threatens to disrupt state policies by upsetting matters beyond the scope of the immediate litigation.

\section{Judicial Development of the Burford Doctrine}

\section{A. The Supreme Court Decisions}

The Burford abstention doctrine, derived from the Supreme Court decision in Burford v. Sun Oil Co., ${ }^{4}$ also rests on the authority of Alabama Public Service Commission v. Southern Railway, ${ }^{5}$ in which the Court relied on Burford in approving abstention. The opinions in these two cases, however, did not provide a clear statement of the doctrine's scope. Justice Black's opinion in Burford explained, with considerable attention to the facts, why abstention was appropriate in the particular case, but failed to state a general principle to guide lower courts in deciding subsequent cases. In Alabama PSC, Chief Justice Vinson's opinion did offer a formulation of greater breadth, but the opinion did not indicate which, if any, of the elements present in Alabama PSC were necessary or sufficient for abstention. And the uncertainty has continued despite subsequent Supreme Court decisions holding abstention improper.

1. Burford v. Sun Oil Co. Burford involved an action by a Texas oil producer to enjoin the execution of an order of the Texas Railroad Commission granting a neighboring leaseholder a permit to drill new wells. The order was attacked as invalid under both state law and the Federal Constitution. ${ }^{6}$ The district court dis-

+ Id.

341 U.S. 341 (1951).

- Jurisdiction was based on both diversity and federal question grounds, 319 U.S. at 317, but the Justices seem to have given serious consideration only to the former ground. The majority opinion focuses on the presence of state-law issues, id. at 319-25, 327-28, 331, making only one passing reference to the presence of a federal claim, id. at 334; the dissent treats the case as solely a matter of honoring diversity jurisdiction, id. at 336-38, 344-46, 348 (Frankfurter, J., dissenting). 
missed the complaint, ${ }^{7}$ the court of appeals reversed, ${ }^{8}$ and the Supreme Court, by a five-to-four vote, held that the district court correctly abstained. ${ }^{9}$

Justice Black, writing for the Court, relied ${ }^{10}$ on the Court's decision two years earlier in Railroad Commission v. Pullman Co., ${ }^{11}$ in which the Court had based a federal court's authority to abstain on its equitable discretion. In Pullman, the plaintiff had sought an injunction against enforcement of an order of the Texas Railroad Commission on the grounds that the order was unconstitutional and that the Commission lacked authority under state law to issue it. On direct appeal, the Supreme Court unanimously held that all federal court proceedings should be stayed to allow an authoritative construction of the relevant statute by the state supreme court. In his opinion for the Court, Justice Frankfurter noted that since the state-law issue was unclear, a federal court could give no more than "a tentative answer which may be displaced tomorrow by a state adjudication." 12 Moreover, if the state court adopted the plaintiff's construction of the relevant statute, a resolution of the federal constitutional question would be unnecessary. ${ }^{13}$ Justice Frankfurter stated that it is within the sound discretion of a federal court to deny equitable relief where granting the relief would adversely affect the public interest:14 "Few public interests have a higher claim upon the discretion of a federal chancellor than the avoidance of needless friction with state policies ...."15 Therefore, he concluded that

7 The district court decision was not reported.

\& The court of appeals first upheld the dismissal and then reversed itself on rehearing. Sun Oil Co. v. Burford, 124 F.2d 467 (5th Cir. 1941), rev'd on rehearing, 130 F.2d 10 (5th Cir. 1942), rev'd, 319 U.S. 315 (1943).

' 319 U.S. at 334.

10 Id. at $332-33,333$ \& n.29.

$" 312$ U.S. 496 (1941).

12 Id. at 500 .

13 The policy of avoiding federal constitutional questions where some other ground disposes of the case is well settled. E.g., Ashwander v. Tennessee Valley Auth., 297 U.S. 288, 346-47 (1936) (Brandeis, J., concurring).

1312 U.S. at 500-01. See Virginia Ry. v. System Fed'n No. 40, 300 U.S. 515, 552 (1937) ("Courts of equity may, and frequently do, go much farther both to give and withhold relief" in furtherance of the public interest than they are accustomed to go when only private interests are involved."); Harrisonville v. W.S. Dickey Clay Mfg. Co., 289 U.S. 334, 338 (1933); Beasley v. Texas \& P. Ry., 191 U.S. 492, 498 (1903); W. DeFuniak, Handbook of Modern Equity 45-46 (1956); D. DobBs, Handbook on the Law of Remedies 65 (1973).

is 312 U.S. at 500. Justice Frankfurter's opinion in Pullman is generally regarded as the leading enunciation of the rationale for federal abstention. Pullman, however, was not the first case in which the Court held that abstention was a proper exercise of equitable discretion to protect state interests. In Pennsylvania v. Williams, 294 U.S. 176 (1935), a diversity action, shareholders of an insolvent state savings association sought appointment of a receiver to 
the proper exercise of equitable discretion required abstention in Pullman to avoid the possibility of error in construing state law and the "friction of a premature constitutional adjudication."16

Unlike Pullman, Burford did not involve a difficult question of statutory construction that might moot the federal constitutional issue. The Court held, however, that abstention in Burford was a proper exercise of equitable discretion: it would avoid undue interference with state interests. The interference in this case lay in the likelihood that the execution of Texas's oil policies would be disrupted if the Commission's orders were subject to review in federal court.

Texas regulated oil production by issuing drilling and operating permits in order to secure for each producer his fair share of oil and to maximize overall recovery from the fields. ${ }^{17}$ These permits were issued according to standards that, despite "delusive simplicity,"18 involved some complex nonlegal problems. ${ }^{19}$ First, operation of any well can have a substantial effect on the production of other wells throughout the field; hence, a decision by the Commission to permit drilling or to adjust production at any well required consideration of the effect on recovery and waste at other wells. ${ }^{20}$ Second, drilling

carry out the association's liquidation. The Pennsylvania Secretary of Banking intervened, asking that the matter be turned over to him for disposition under the state's established administrative mechanism for liquidation of state banks. The Court noted that "[i]t is in the public interest that federal courts of equity should exercise their discretionary power with proper regard for the rightful independence of state governments in carrying out their domestic policy," id. at 185 , and that the state administrative procedures would adequately protect the interests of all concerned parties, id. at 186.

16 312 U.S. at 500. The Pullman rule, as it has been shaped since 1941, is that a federal court should postpone "exercise of its jurisdiction in cases presenting a federal constitutional issue which might be mooted or presented in a different posture by a state court determination of pertinent state law." County of Allegheny v. Frank Mashuda Co., 360 U.S. 185, 189 (1959). See Developments in the Law-Section 1983 and Federalism, 90 HaRv. L. Rev. 1133, 1250-54 (1977). The state-law issue must not only be potentially dispositive of the case without the need for a decision on the constitutional issue, but it must also be uncertain or unclear. E.g., Wisconsin v. Constantineau, 400 U.S. 433 (1971); 1A J. MoorE, supra note 1, If 0.203[1], at 2106; C. Wright, HaNDBooK of the LaW of THe Federal Courts $\$ 52$, at 219 (3d ed. 1976). On the development and scope of the Pullman doctrine, see 17 C. WRIGHT, A. Mnler \& E. Cooper, supra note 1, § 4242; Field, Abstention in Constitutional Cases: The Scope of the Pullman Abstention Doctrine, 122 U. PA. L. REv. 1071 (1974).

17319 U.S. 320-21. For a more detailed description of the oil field, the regulatory problems it presents, and Texas's solution to them, see id. at 318-25; Railroad Comm'n v. Rowan \& Nichols Oil Co., 310 U.S. 573, 578-80 (1940), 311 U.S. 570, 574-75 (1941).

18319 U.S. at 323. In Burford, the dispute was over exceptions to rules stipulating minimum spacing between wells. A Commission rule allowed exceptions "where necessary 'to prevent waste or to prevent confiscation of property.'" Id. at 322.

1" Id. at 318-20, 323-25.

${ }^{20} \mathrm{Id}$. at $318-20$. Production in one well might affect production at wells a considerable distance away. $I d$. at 319,324 . 
and production decisions were based on imprecise geological data. ${ }^{21}$ Third, surface rights in the field were split into many small tracts, adding to the Commission's other problems the need to avoid practical confiscation of any producer's rights..$^{22}$ Accordingly, the Commission was obliged to grant numerous exceptions to its general standards, in effect regulating the field on a case-by-case basis..$^{23}$ Finally, regulation had to be conducted with caution because disruption of the oil industry could adversely affect the economy and public revenues of the state. ${ }^{24}$

Because of these problems, the state had set up a special system for judicial review of the Commission's orders. Jurisdiction was conferred exclusively on the state district courts of the capital county. ${ }^{25}$ Concentration of judicial review allowed the reviewing courts to develop expertise in oil regulation and reduced the likelihood of inconsistent decisions that might result from parallel lines of review. The courts also exercised exceptionally broad authority. They could, for example, undertake de novo review ${ }^{26}$ of the Commission's orders and propose regulatory standards for adoption by the Commission. ${ }^{27}$

Justice Black noted both the complex problems attending oil regulation and the special role of the state courts. Review of the Commission's orders by federal courts, he concluded, was likely to result in the erroneous and inconsistent decisions and disruption of state policy that the state system was designed to avoid. Justice Black stressed the need for continuity in regulatory policy, declaring that drilling decisions should be "handled as "one more item in a

21 Id. at 322 .

22 Id. at 319.

2 See id. at 324. It was estimated that two-thirds of the wells in the field existed as exceptions to the rule at issue in Burford. Id.

21 Id. at 320.

${ }^{25}$ Id. at 325; Tex. Stat. AnN. art. 6049c, $\$ 8$ (Vernon 1936) (current version at Tex. REv. Civ. Stat. AnN. art. 6049c(8) (Vernon 1962)).

319 U.S. at 326 (citing Railroad Comm'n v. Shell Oil Co., 139 Tex. 66, 161 S.W.2d 1022 (1942)).

${ }_{27} 319$ U.S. at 326 . Justice Black described the Texas courts as "working partners with the Railroad Commission in the business of creating a regulatory system for the oil industry." Id. Justice Douglas, in a concurring opinion joined by Justice Murphy (both Justices also joining the opinion of the Court), added that "the courts may at times be the senior and dominant member of that partnership." Id. at 335 (Douglas, J., concurring). Justice Douglas found this to be "the crux of the matter." Id. If the federal courts were to exercise this broad review power, "they would in effect actively participate in the fashioning of the state's domestic policy." Id. This degree of interference, he concluded, required a federal court of equity to defer to the state courts. Id. at 335-36. See also text and notes at notes 147-155 infra. 
continuous series of adjustments." "28 In support of this conclusion, he referred to the results of previous federal injunctions, which had in fact caused considerable disruption. ${ }^{29}$ In addition, he observed that review in the state courts was "expeditious and adequate" and that the state proceeding would preserve any federal questions for ultimate review in the United States Supreme Court..$^{30}$ Justice Black concluded that in these circumstances the federal court should withhold its jurisdiction in deference to the state's interests. ${ }^{31} \mathrm{He}$ characterized this course as an exercise of equitable discretion, but did not attempt to state a general rule to guide future decisions.

2. Alabama Public Service Commission v. Southern Railway. Eight years later, the Supreme Court, relying on Burford, found abstention proper in Alabama PSC. ${ }^{32}$ The Alabama Public Service Commission had denied Southern Railway's application for permission to discontinue passenger service on two intrastate train lines. Southern claimed that it was losing money on the lines because of decreased use, but the Commission found that the public needed the service and that Southern had not attempted to cut costs. Its application denied, Southern brought an action in federal court to enjoin enforcement of the Commission's order, alleging that the Commission's denial amounted to confiscation in violation of the due process clause. ${ }^{33}$ A three-judge court, undertaking a de novo review, granted the injunction; ${ }^{34}$ the Supreme Court reversed, holding that the district court should have abstained..$^{35}$ Chief Justice Vinson, writing for the Court, cited ${ }^{36}$ Burford and listed three factors

${ }^{28} 319$ U.S. at 332 (quoting Railroad Comm'n v. Rowan \& Nichols Oil Co., 310 U.S. 573, $584(1940))$.

29319 U.S. at $327-28,332$.

${ }^{30} \mathrm{Id}$. at $333-34$.

3t "[A] sound respect for the independence of state action requires the federal equity court to stay its hand." Id. Justice Frankfurter, in a dissenting opinion joined by two other Justices (Roberts \& Reed, JJ.) and concurred in by a fourth (Stone, C.J.) argued that the congressional grant of diversity jurisdiction bound the courts and precluded the use of equitable jurisdiction to modify its reach. Id. at 336-48 (Frankfurter, J., dissenting). See text and notes at notes 102-109 infra.

32341 U.S. 341 (1951).

${ }^{33}$ U.S. CONST. amend. XIV, \& 1. Jurisdiction was based on both federal question and diversity grounds, 341 U.S. at 344 . The latter allegation appears to have been superfluous, since no state-law claims were presented. See id. at 355, 358-59, 362 (Frankfurter, J., concurring in the result) (addressing only issues of federal question jurisdiction).

34 Southern Ry. v. Alabama Pub. Serv. Comm'n, 91 F. Supp. 980 (M.D. Ala. 1950), rev'd, 341 U.S. 341 (1951).

${ }^{35} 341$ U.S. at $345,350$.

36 Id. 
demanding abstention in Alabama PSC. First, the suit involved "the essentially local problem of balancing the loss to the railroad from continued operation . . . with the public need for that service." 37 Second, Alabama had concentrated judicial review of the Commission's orders in one circuit. ${ }^{38}$ Third, the reviewing courts exercised a relatively broad scope of authority..$^{39}$

Although these factors resemble those set forth by the Court in Burford, the requirements for abstention appear to be much less stringent in Alabama PSC than in Burford. ${ }^{40}$ Whereas Justice Black explained in considerable detail how federal adjudication could interfere with the implementation of Texas's oil policies, Chief Justice Vinson merely noted that the issue before the Court was a policy matter of local concern; he did not contend that federal adjudication threatened to disrupt state policy. Similarly, whereas Justice Black showed that the concentration of judicial review under the Texas scheme fostered judicial expertise and avoided inconsistent decisions in a complex regulatory system, Chief Justice Vinson did not show that Alabama's scheme of judicial review served any like purpose.

Indeed, the Chief Justice's statement of the holding in Alabama $P S C$, if taken literally, is very broad:

As adequate state review . . . is available to appellee, intervention of a federal court is not necessary for the protection of federal rights. Equitable relief may be granted only when the District Court . . . is convinced that the asserted federal right cannot be preserved except by granting the "extraordinary relief of an injunction in the federal courts." "I

${ }^{37}$ Id. at $347-48$.

3 Id. at 348. It is not clear, however, that judicial review was in fact concentrated. The statutory provision read: "From any final action or order of the commission . . . an appeal therefrom shall lie to the circuit court of Montgomery County." ALA. CoDE $\$ 48-79$ (1940) (current version at ALA. CODE $\S 37-1-120$ (1975)). There is no case law commenting on whether this provided for exclusive review in the Montgomery County courts. Indeed, one of the Alabama decisions cited by Chief Justice Vinson involved an order originally adjudicated in another county. Avery Freight Lines, Inc. v. White, 245 Ala. 618, 18 So. 2d 394 (1944).

33 The circuit court could set aside an order that was based upon an error of law that prejudiced the "substantial rights" of an appellant, that was procured by fraud, or that was based upon a finding of facts "contrary to the substantial weight of the evidence" presented before the agency. ALA. CODE $\S 48-82$ (1940) (current version at ALA. ConE $\S 37-1-124$ (1975)). Chief Justice Vinson relied on an opinion of the Supreme Court of Alabama to label this review "supervisory in character," 341 U.S. at 348 (quoting Avery Freight Lines, Inc. v. White, 245 Ala. 618,62318 So. $2 \mathrm{~d} 394,398$ (1944)). When a challenge to an administrative order included a charge of confiscation in violation of due process (as Alabama PSC did) the court undertook an independent finding of law and fact. 341 U.S. at 348 (citing Alabama Pub. Serv. Comm'n v. Southern Bell Tel. \& Tel. Co., 253 Ala. 1, 11-12, 42 So. 2d 655, 662 (1949)).

10 See also 1A J. Moore, supra note 1, ๆ 0.203[2].

4341 U.S. at 349-50 (footnotes omitted). 
Under this formulation, it might appear that abstention should be the general rule in cases that involve review of state administrative orders and present issues of local concern. Such a rule, though, would be at odds with the Court's statements elsewhere that abstention is appropriate in only "exceptional" circumstances. ${ }^{42}$ It seems more reasonable to suppose that the factors listed by Chief Justice Vinson were considered somehow significant as limits on abstention, though their precise relevance is unexplained.

3. Further Supreme Court Development. There has been little discussion of Burford abstention by the Supreme Court since Alabama PSC. ${ }^{43}$ In McNeese $v$. Board of

12 E.g., Meredith v. Winter Haven, 320 U.S. 228, 234 (1943). The Alabama PSC opinion noted the Meredith case, but dismissed it in a rather cursory manner. 341 U.S. at 351 n.15. The Alabama PSC holding also appears to differ from Justice Douglas's view of Burford, expressed in his Burford concurrence: "[T] he opinion of the Court as I read it does not hold or even fairly imply that "the enforcement of state rights created by state legislation and affecting state policies is limited to the state courts.' " 319 U.S. at 334 (Douglas, J., concurring).

Justice Frankfurter concurred in the result in Alabama PSC but objected to the abstention holding, arguing that it would effectively repeal the grant of general federal question jurisdiction. 341 U.S. at 361 (Frankfurter, J., concurring in the result).

t3 Eight years after Alabama PSC, the Court, without reference to Burford, affirmed a district court's abstention in Louisiana Power \& Light Co. v. City of Thibodaux, 360 U.S. 25 (1959). Although the rationale for abstention in Thibodaux was similar to that in Burford and Pullman, it represents a third and distinct brand of abstention. The dispute in Thibodaux arose out of a proceeding by the city to take by eminent domain property owned by the utility company. The company removed the proceeding to federal court on the basis of diversity of citizenship. The main controversy in the case was whether, as a matter of state law, municipalities had the authority to condemn public utility properties. In an opinion written by Justice Frankfurter, the Court held abstention proper because the state-law issue was novel and difficult, so that the federal court construction of law could only be "a dubious and tentative forecast, and the subject matter was particularly important to state autonomy." $I d$. at 29.

On the same day that the Court decided Thibodaux, it reversed a district court absten. tion in another eminent domain case, remarking that "eminent domain . . . [is not] mystically involved with the 'sovereign prerogative.' " County of Allegheny v. Frank Mashuda Co., 360 U.S. 185, 192 (1959). Some commentators have understandably expressed difficulty in reconciling the two outcomes. E.g., 1A J. Moore, supra note 1, IJ 0.203[2], at 2121-22; C. WrIGHT, supra note $16, \S 52$, at 222-23. See also Field, supra note 16, at 1148-53. Despite the contradictory language used in the respective majority opinions, it seems clear that the two holdings are distinguishable in that the key feature in Thibodaux-an unclear question of state law-was not present in Mashuda. Thibodaux, 360 U.S. at 31 (Stewart, J., concurring). Compare id. with Mashuda, 360 U.S. at 190 . But note the similarity of the "factual issue" in Mashuda to the "legal issue" in Kaiser Steel Corp. v. W.S. Ranch Co., 391 U.S. 593 (1968) (per curiam).

The Court has recently characterized Thibodaux abstention as appropriate "where there have been presented difficult questions of state law bearing on policy problems of substantial public import whose importance transcends the result in the case then at bar." Colorado River Water Conservation Dist. v. United States, 424 U.S. 800, 814 (1976) (citing Thibodaux 
Education, ${ }^{44}$ the plaintiffs bypassed a state administrative procedure established to hear complaints concerning school segregation and sued in federal court for an order to desegregate a public school. The Court declined to order abstention, pointing out that the purpose of the suit in Burford was "to enjoin enforcement of a state administrative order enforcing state law," 45 while in $M c N e e s e$ there was "no underlying issue of state law controlling [the] litigation." The Court did not acknowledge, however, that the same point would distinguish Alabama PSC, which was based on a due process claim, from Burford.

In Colorado River Water Conservation District v. United States, ${ }^{47}$ the United States brought an action in federal court to establish water rights for its own lands and for Indian lands in Colorado. Although the Court acknowledged that Colorado had a strong interest in the allocation of water rights and that the state had established special procedures to adjudicate disputes over water rights, ${ }^{48}$ it refused to order Burford abstention. ${ }^{49}$ The Court admitted that a federal court might reach results different from

and Kaiser Steel Corp. v. W. S. Ranch Co., 391 U.S. 593 (1968)). The Court's opinion in Colorado River puts Burford and Thibodaux into a single category of abstention, but distinguishes between them on the ground that Thibodaux involved a difficult legal question with decisive impact on the substance of state policy, while Burford abstention involves decisionmaking not itself determinative of state policy but which might have a practical impact on implementation of a state policy. 424 U.S. at 814-15.

The Thibodaux doctrine goes against the established rule that difficulties in ascertaining state law do not, in themselves, afford a sufficient ground for abstention. Meredith v. Winter Haven, 320 U.S. 228, 234 (1943). See also Colorado River, 424 U.S. at 816. Apparently Thibodaux creates an exception where state-law questions are especially important. See also note 104 infra. See generally 17 C. WRIGHT, A. MiLLER \& E. CoOper, supra note 1, § 4246; Gowen \& Izlar, Federal Court Abstention in Diversity of Citizenship Litigation, 43 TEx. L. REv. 194, 200-14 (1964); Note, Louisiana Power \& Light Co. v. Thibodaux: The Abstention Doctrine Expanded, 69 YALE L.J. 643 (1960). For a lucid discussion of the tangle created by Meredith, Thibodaux, and Mashuda, see Dome Condominium Ass'n v. Goldenberg, 442 F. Supp. 438 (S.D. Fla. 1977).

" 373 U.S. 668 (1963).

15 Id. at 673.

4t Id. at 674. Justice Harlan dissented, arguing that the Court should order abstention on the authority of Burford because the state procedures appeared adequate to resolve the issue and because the alleged discriminatory practices related "to the manner in which this particular school district was formed and to the way in which the internal affairs of the school are administered," matters that "are much better left to local authority." Id. at 677 (Harlan, J., dissenting).

47424 U.S. 800 (1976).

4s Id. at 804-05.

13 The Court dismissed the action in deference to a parallel state court proceeding, id. at 817-21, but made it clear that this basis for dismissal was entirely separate from traditional abstention in the interests of federalism or of avoiding constitutional issues, id. at 817. See generally Comment, Federal Court Stays and Dismissals in Deference to Parallel State Court Proceedings: The Impact of Colorado River, 44 U. CH. L. Rev. 641 (1977). 
those of a state tribunal, but such inconsistency would not "impair impermissibly the State's efforts to effect its policy"50 as it did in Burford.

The disinclination of the Court to order Burford abstention in these cases suggests that, despite the broad language in Alabama $P S C$, the Court does intend to confine the doctrine to certain particular circumstances. Neither case, however, makes explicit what those circumstances are..$^{51}$

\section{B. Lower-Court Applications of Burford Abstention}

With such limited guidance from the Supreme Court, the lower federal courts have predictably reached diverse conclusions about the proper application of the Burford doctrine. Indeed, the cases following Burford and Alabama PSC reflect considerable confusion about the significance of the major elements of the two cases.

1. Disruption of State Policies. Burford differs markedly from Alabama PSC in that it treated potential disruption of a state's regulatory scheme as the central reason for abstention. Alabama $P S C$, on the other hand, ordered abstention without the slightest mention of this factor. The recent decision in Colorado River, however, took Burford at its word, and therefore denied abstention on the ground that no possibility of disruption had been demonstrated. ${ }^{52}$

Lower courts have ordered abstention without referring to potential disruption in a number of cases both before $\mathrm{e}^{53}$ and

so 424 U.S. at 815. This restrictive reading of Burford was followed in Zablocki v. Redhail, 434 U.S. 374,379 n.5 (1978).

st The Alabama PSC opinion did not even note the potential for inconsistent decisions. Despite the Court's failure to mention that possibility, Burford and Alabama PSC should not be treated as separate abstention doctrines. All of the reasons for abstaining in Alabama PSC' also applied in Burford. Thus, Burford abstention could, at best, be an aberrant subset of Alabama PSC abstention. The case law and commentary tend strongly to classify the two together. See, e.g., Colorado River Water Conservation Dist. v. United States, 424 U.S. 800 , 814-15, 815 \& n.21 (1976); 1A J. Moore, supra note 1, ๆ 0.203[2], at 2123-30.1; C. WRIGHT, supra note $16, \S 52$, at 222 . Occasionally, an opinion will cite one without the other, but rarely will a court attempt to treat the two cases as distinct. But see County of Allegheny v. Frank Mashuda Co., 360 U.S. 185, 189-90 (1959).

Burford abstention has also been briefly described in dicta in Zwickler v. Koota, 389 U.S. 241, 249 n.11 (1967); County of Allegheny v. Frank Mashuda Co., 360 U.S. 185, 189 (1959); Meredith v. Winter Haven, 320 U.S. 228, 235 (1943). See also Gulf Oil Corp. v. Gilbert, 330 U.S. 501, 505 (1947) (citing Burford as an example of forum non conveniens).

32424 U.S. at $815-16$.

ss Tennyson v. Gas Serv. Co., 506 F.2d 1135, 1143 (10th Cir. 1974) (alternative holding); Simmons v. Jones, 478 F.2d 321, 327-28 (5th Cir. 1973), modified per curiam, 519 F.2d 52 (5th Cir. 1975); City of Monroe v. United Gas Corp., 253 F.2d 377, 380-81 (5th Cir. 1958) (alternative holding); Atlantic Coast Line R.R. v. City of St. Petersburg, 242 F.2d 613, 61516 (5th Cir. 1957); General Inv. \& Serv. Corp. v. Wichita Water Co., 236 F.2d 464, 467-68 
after $^{54}$ Colorado River. In other cases, courts have mentioned potential disruption as a significant consideration, but have made no real effort to demonstrate the potential for disruption in the case at hand. ${ }^{55}$

Many courts, however, have required a showing of the potential for disruption. Among those courts, a few have found the threat of disruption sufficient to justify abstention. Courts have, for example, abstained in actions where judicial relief might upset insurance rate structures $^{58}$ or where judicial relief might allow regulated firms to

(10th Cir. 1956) (alternative holding); Surowitz v. New York City Employees' Retirement Sys., 376 F. Supp. 369, 373-76 (S.D.N.Y. 1974) (alternative holding); Safeguard Mut. Ins. Co. v. Pennsylvania, 372 F. Supp. 939, 952 (E.D. Pa. 1974) (alternative holding); Meicler v. Aetna Cas. \& Sur. Co., 372 F. Supp. 509, 515 (S.D. Tex. 1974), aff'd on other grounds, 506 F.2d 732 (5th Cir. 1975); Alwin Constr. Co. v. Lufkin, 360 F. Supp. 1119 (D. Conn. 1973); Mountain States Tel. \& Tel. Co. v. Public Utils. Comm'n, 345 F. Supp. 80, 86-88 (D. Colo. 1972) (alternative holding); Egner v. Texas City Independent School Dist., 338 F. Supp. 931, 94143 (S.D. Tex. 1972) (alternative holding); Pervis v. LaMarque Independent School Dist., 328 F. Supp. 633, 644 (S.D. Tex. 1971) (dictum), rev'd on other grounds, 466 F.2d 1054 (5th Cir. 1972); Press v. Pasadena Independent School Dist., 326 F. Supp. 550, 553-58 (S.D. Tex. 1971); Schwartz v. Galveston Independent School Dist., 309 F. Supp. 1034, 1045-46, 1048-49 (S.D. Tex. 1970) (alternative holdings); Ali v. Division of State Athletic Comm'n, 308 F. Supp. 11, 19 (S.D.N.Y. 1969) (dictum), relief granted on new pleadings, 316 F. Supp. 1246 (S.D.N.Y. 1970); Wreiole v. Waterfront Comm'n, 132 F. Supp. 166, 168-69 (S.D.N.Y. 1955); General Tel. Co. v. Robinson, 132 F. Supp. 39, 45-46 (E.D. Ark. 1955); Applegate v. Waterfront Comm'n, 129 F. Supp. 71 (S.D.N.Y. 1955); Walgreen Co. v. Taylor, 127 F. Supp. 657 (D. Minn.), mandamus denied sub nom. Walgreen Co. v. Donovan, 227 F.2d 165 (8th Cir. 1955); Gulf, M. \& O.R. Co. v. Louisiana Pub. Serv. Comm'n, 120 F. Supp. 250, 253-54 (E.D. La. 1954); Bowers v. Calkins, 84 F. Supp. 272, 279 (D.N.H. 1949).

st Garrett v. Bamford, 582 F.2d 810, 819 (3d Cir. 1978); Gray-Taylor, Inc. v. Harris County, 569 F.2d 893 (5th Cir.) (per curiam), cert. denied, 439 U.S. 954 (1978); Kelly Servs., Inc. v. Johnson, 542 F.2d 31 (7th Cir. 1976); Forest Hills Util. Co. v. City of Heath, 539 F.2d 592 (6th Cir. 1976); Kent Island Joint Venture v. Smith, 452 F. Supp. 455, 461-63 (D. Md. 1978); Stallworth v. City of Monroeville, 426 F. Supp. 236 (S.D. Ala. 1976). Cf. Allstate Ins. Co. v. Sabbagh, 603 F.2d 228 (1st Cir. 1979) (recognizing Colorado River, but failing to follow it correctly); Barry v. St. Paul Fire \& Marine Ins. Co., 555 F.2d 3, 12 (1st Cir. 1977) (same), aff'd on other grounds, 438 U.S. 531 (1978); Cristina v. Department of State, 417 F. Supp. 1012 (S.D.N.Y. 1976) (same); Santa Fe Land Improvement Co. v. City of Chula Vista, 71 F.R.D. 573 (S.D. Cal. 1976) (same), rev'd in relevant part, 596 F.2d 838 (9th Cir. 1979). Some of these cases were argued prior to the Colorado River decision, but all were decided substantially afterwards.

ss AFA Distrib. Co. v. Pearl Brewing Co., 470 F.2d 1210 (4th Cir. 1973) (alternative holding); Gregg v. Winchester, 173 F.2d 512, 515 (9th Cir.) (alternative holding), cert. denied, 338 U.S. 847 (1949); Bridgeport Hydraulic Co. v. Council on Water Co. Lands, 453 F. Supp. 942, 950 (D. Conn. 1977) (alternative holding), aff'd mem., 99 S. Ct. 606 (1978); Zucker v. Bell Tel. Co., 373 F. Supp. 748, 756 (E.D. Pa. 1974) (alternative holding), aff'd mem., 510 F.2d 971 (3d Cir.), cert. denied, 422 U.S. 1027 (1975); Giorgi v. Pennsylvania Labor Relations Bd., 293 F. Supp. 873, 875 (E.D. Pa. 1968); Allegheny Airlines, Inc. v. Fowler, 261 F. Supp. 508, 522 (S.D.N.Y. 1966) (alternative holding); Harris v. Connecticut Light \& Power Co., 125 F. Supp. 395, 397-98 (D. Conn. 1954), aff'd per curiam, 221 F.2d 958 (2d Cir. 1955).

st Allstate Ins. Co. v. Sabbagh, 603 F.2d 228, 232 n.4 (1st Cir. 1979) (dictum); Construc- 
circumvent a state law requiring approval for the discontinuation of transportation services. ${ }^{57}$ Abstention has also been ordered where the case challenged the sole application of a particular state policy ${ }^{5 \mathrm{~K}}$ or presented an unguided choice between conflicting state policies.5 And in a case involving a number of similar local plans established to conform with state requirements, the court ordered abstention, fearing that striking down one local plan might upset the state-wide system. ${ }^{60}$

Most of the courts that have required a showing of potential disruption, however, have found no serious threat of disruption and have therefore refused to order abstention. ${ }^{61}$ In particular, courts have usually found no potential disruption of state policy in cases involving challenges to internal procedures of state agencies on due process grounds. In these cases, the courts have reasoned that only the challenged procedures themselves would be disturbed by the requested relief..$^{62}$ Similarly, courts have found no potential disrup-

tion Aggregates Corp. v. Rivera de Vicenty, 573 F.2d 86, 96 (1st Cir. 1978) (refusing abstention on other issues); Barry v. St. Paul Fire \& Marine Ins. Co., 555 F.2d 3, 12-13 (1st Cir. 1977), aff'd on other grounds, 438 U.S. 531 (1978).

${ }_{57}$ Allegheny Airlines, Inc. v. Pennsylvania Pub. Util. Comm'n, 465 F.2d 237 (3d Cir. 1972), cert. denied, 410 U.S. 943 (1973).

ss Urbano v. Board of Managers, 415 F.2d 247 (3d Cir. 1969), cert. denied, 397 U.S. 948 (1970).

${ }^{59}$ Barrett v. Atlantic Richfield Co., 444 F.2d 38 (5th Cir. 1971); Cristina v. Department of State, 417 F. Supp. 1012 (S.D.N.Y. 1976).

60 Santa Fe Land Improvement Co. v. City of Chula Vista, 71 F.R.D. 573 (S.D. Cal. 1976), rev'd in relevant part, 596 F.2d 838 (9th Cir. 1979). See also Brown v. First Nat'l City Bank, 503 F.2d 114, 117-18 (2d Cir. 1974) (dictum).

61 Santa Fe Land Improvement Co. v. City of Chula Vista, 596 F.2d 838, 841-42 (9th Cir. 1979); Campbell v. McGruder, 580 F.2d 521, 525 (D.C. Cir. 1978); Garvin v. Rosenau, 455 F.2d 233, 238-39 (6th Cir. 1972); Robertsen v. State Farm Mut. Auto. Ins. Co., 464 F. Supp. 876, 878-79 (D.S.C. 1979) (by implication); Prochaska v. Fediaczko, 458 F. Supp. 778, 780 (W.D. Pa. 1978); Barbaccia v. County of Santa Clara, 451 F. Supp. 260, 264 (N.D. Cal. 1978); Nehring v. Ariyoshi, 443 F. Supp. 228, 234-35 (D. Hawaii 1977); M.J. Brock \& Sons v. City of Davis, 401 F. Supp. 354, 357-58 (N.D. Cal. 1975); Steel Hill Dev., Inc. v. Town of Sanbornton, 335 F. Supp. 947, 951-52 (D.N.H. 1971); Lerner v. Town of Islip, 272 F. Supp. 664, 66768 (E.D.N.Y. 1967); Joe Louis Milk Co. v. Hershey, 243 F. Supp. 351, 357 (N.D. Ill. 1965); Seiden v. Boone, 221 F. Supp. 845 (D. Del. 1963); cases cited notes 62-64 infra.

62 Allstate Ins. Co. v. Sabbagh, 603 F.2d 228, 232 (1st Cir. 1971) (dictum); Escalera v. New York City Hous. Auth., 425 F.2d 853, 885 (2d Cir.), cert. denied, 400 U.S. 853 (1970); Holmes v. New York City Hous. Auth., 398 F.2d 262, 266 (2d Cir: 1968); Santiago v. City of Philadelphia, 435 F. Supp. 136, 145 (E.D. Pa. 1977); Jeter v. Kerr, 429 F. Supp. 435, 439-40 (S.D.N.Y. 1977); Dawes v. Philadelphia Gas Comm'n, 421 F. Supp. 806, 826-27 (E.D. Pa. 1976); Clutchette v. Procunier, 328 F. Supp. 767, 772 (N.D. Cal. 1971), modified and aff'd, 497 F.2d 809 (9th Cir. 1974); Carothers v. Follette, 314 F. Supp. 1014, 1019-20 (S.D.N.Y. 1970). See Ktsanes v. Underwood, 467 F. Supp. 1002, 1007 (N.D. Ill. 1979) (equal protection claim). Contra, Allegheny Airlines, Inc. v. Pennsylvania Pub. Util. Comm'n, 465 F.2d 237 (3d Cir. 1972), cert. denied, 410 U.S. 943 (1973). 
tion in cases in which the issue presented was whether the plaintiffs' activities fell within a particular regulated area. These courts have reasoned that the exclusion of one category from the scheme would not seriously disturb the overall regulatory program..$^{63}$ Finally, a few courts, relying on the absence of an intricate regulatory system or on the fact that no special expertise was necessary to decide the issue at hand, have found that no disruption was likely.$^{64}$

2. Special State Court Expertise. In Burford, the Court noted that concentration of judicial review had enabled the state courts to develop a "special knowledge" of the complicated issues that arise in cases involving oil regulation. ${ }^{65}$ But neither Alabama PSC ${ }^{\text {is }}$ nor the Court's later decisions refusing abstention ${ }^{67}$ have mentioned special expertise. Most lower courts have ignored it as well. A few courts that have refused abstention have pointed out that the state courts had no special competence in the matter being litigated; ${ }^{68}$ one abstaining court concluded that they did. ${ }^{69}$ Other opinions seem to suggest that Burford abstention may be based on deference to the expertise of state administrative agencies. ${ }^{70}$

w Construction Aggregates Corp. v. Rivera de Vicenty, 573 F.2d 86, 93, 95-96 (1st Cir. 1978) (approving abstention on other issues); Moreno v. University of Md., 420 F. Supp. 541, 552 (D. Md. 1976), aff'd sub nom. Moreno v. Elkins, 556 F.2d 573 (4th Cir.), question certified to state court, 435 U.S. 647 (1978), remanded sub nom. Toll v. Moreno, 99 S. Ct. 2044 (1979); Cosgrove v. First \& Merchants Nat'l Bank, 68 F.R.D. 555, 558 (E.D. Va. 1975). Cf. BT Inv. Managers, Inc. v. Lewis, 559 F.2d 950, 954-55 (5th Cir. 1977) (attack on one statute not disruptive of remaining scheme), prob. juris. noted, 100 S. Ct. 41 (1979). Contra, Kelly Servs., Inc. v. Johnson, 542 F.2d 31 (7th Cir. 1976); Allegheny Airlines, Inc. v. Fowler, 261 F. Supp. 508, 522 (S.D.N.Y. 1966).

" Baltimore Bank for Coops. v. Farmers Cheese Coop., 583 F.2d 104, 109 (3d Cir. 1978); Ktsanes v. Underwood, 467 F. Supp. 1002, 1007 (N.D. Ill. 1979); Bracco v. Lackner, 462 F. Supp. 436, 451 (N.D. Cal. 1978); Pettit v. Gingerich, 427 F. Supp. 282, 286 (D. Md. 1977), aff'd per curiam, 582 F.2d 869 (4th Cir. 1978); Moreno v. University of Md., 420 F. Supp. 541, 552 (D. Md. 1976), aff'd sub nom. Moreno v. Elkins, 556 F.2d 573 (4th Cir.), question certified to state court, 435 U.S. 647 (1978), remanded sub nom. Toll v. Moreno, $99 \mathrm{~S}$. Ct. 2044 (1979); Lerner v. Town of Islip, 272 F. Supp. 664, 667-68 (E.D.N.Y. 1967).

as 319 U.S. at 327.

"See text and notes at notes 36-42 supra.

7 See text and notes at notes 44-51 supra.

cs Santa Fe Land Improvement Co. v. City of Chula Vista, 596 F.2d 838, 842 (9th Cir. 1979); Wynn v. Carey, 582 F.2d 1375, 1383 (7th Cir. 1978); BT Inv. Managers, Inc. v. Lewis, 559 F.2d 950, 955 (5th Cir. 1977), prob. juris. noted, 100 S. Ct. 41 (1979); Penagaricano v. Allen Corp., 267 F.2d 550, 557 (1st Cir. 1959); Romero v. Weakley, 226 F.2d 399, 402 (9th Cir. 1955); Ktsanes v. Underwood, 467 F. Supp. 1002, 1007 (N.D. Ill. 1979); Bracco v. Lackner, 462 F. Supp. 436, 451 (N.D. Cal. 1978); Clutchette v. Procunier, 328 F. Supp. 767, 772 (N.D. Cal. 1971), modified and aff'd, 497 F.2d 809 (9th Cir. 1974). Cf. Wincamp Partnership v. Anne Arundel County, 458 F. Supp. 1009, 1020 (D. Md. 1978) (issue presented no difficulties).

" Stallworth v. City of Monroeville, 426 F. Supp. 236, 240 (S.D. Ala. 1976).

70 Surowitz v. New York City Employees' Retirement Sys., 376 F. Supp. 369, 377 
3. Exclusive State Judicial Remedy. An element mentioned in both Burford and Alabama PSC was the concentration of judicial review in the courts of the capital county. ${ }^{71}$ This concentration was noted in order to stress the integration of state court review into the regulatory scheme. Justice Douglas's concurring opinion in Burford pointed out that concentration reduced conflicting decisions and fostered judicial expertise. ${ }^{72}$ In subsequent cases, however, the Court has never mentioned geographic concentration of review or the existence of an exclusive means of review. These elements have been ignored in all the later Supreme Court statements ${ }^{73}$ concerning Burford abstention and in nearly all lower-court decisions ordering abstention, ${ }^{74}$ and only a handful of cases cite the lack of an exclusive judicial remedy as a ground for refusing to abstain. ${ }^{75}$

Moreover, among the few cases in which exclusive judicial remedy has been cited as a reason for abstaining, none has involved an exclusive judicial procedure of the type present in Burford and Alabama PSC: geographic concentration of judicial review. ${ }^{76}$ In two

(S.D.N.Y 1974); Mountain States Tel. \& Tel. Co. v. Public Utils. Comm'n, 345 F. Supp. 80, 86-88 (D. Colo. 1972). Cf. Railroad Comm'n v. Rowan \& Nichols Oil Co., 310 U.S. 573, 583 (1940) (agency expertise relevant to narrow scope of due process review).

" 319 U.S. at $326-28 ; 341$ U.S. at 348 . But see note 38 supra.

${ }^{72}$ See note 27 supra. See also text and notes at notes 147-155 infra.

${ }^{73}$ Zablocki v. Redhail, 434 U.S. 374, 379 n.5 (1978); Colorado River Water Conservation Dist. v. United States, 424 U.S. 800, 814-16 (1976); McNeese v. Board of Educ., 373 U.S. 668, 673-74 (1963); County of Allegheny v. Frank Mashuda Co., 360 U.S. 185, 189-90 (1959); Meredith v. Winter Haven, 320 U.S. 228, 234-35 (1943). The Court in all of these cases refused to allow Burford abstention, but lack of exclusive review was never cited as a reason for refusing.

${ }^{74}$ E.g., Kelly Servs., Inc. v. Johnson, 542 F.2d 31 (7th Cir. 1976); Urbano v. Board of Managers, 415 F.2d 247 (3d Cir. 1969), cert. denied, 397 U.S. 948 (1970); Atlantic Coast Line R.R. v. City of St. Petersburg, 242 F.2d 613 (5th Cir. 1957); Meicler v. Aetna Cas. \& Sur. Co., 372 F. Supp. 509 (S.D. Tex.), aff'd on other grounds, 506 F.2d 732 (5th Cir. 1975); Harris v. Connecticut Light \& Power Co., 125 F. Supp. 395 (D. Conn. 1954), aff'd per curiam, 221 F.2d 958 (2d Cir. 1955).

${ }^{35}$ Santa Fe Land Improvement Co. v. City of Chula Vista, 596 F.2d 838, 841-42 (9th Cir. 1979); Campbell v. McGruder, 580 F.2d 521, 525 (D.C. Cir. 1978); Rancho Palos Verdes Corp. v. City of Laguna Beach, 547 F.2d 1092, 1096 (9th Cir. 1976); Holmes v. New York City Hous. Auth., 398 F.2d 262, 267 (2d Cir. 1968); Penagaricano v. Allen Corp., 267 F.2d 550, 557 (1st Cir. 1959); Moreno v. University of Md., 420 F. Supp. 541, 552 (D. Md. 1976), aff'd sui nom. Moreno v. Elkins, 556 F.2d 573 (4th Cir.), question certified to state court, 435 U.S. 647 (1977), remanded sub nom. Toll v. Moreno, 99 S. Ct. 2044 (1979); Lerner v. Town of Islip, 272 F. Supp. 664, 667-68 (E.D.N.Y. 1967); Joe Louis Milk Co. v. Hershey, 243 F. Supp. 351, 357 (N.D. Ill. 1965); Seiden v. Boone, 221 F. Supp. 845, 846-47 (D. Del. 1963).

${ }^{76}$ In one case, geographically concentrated state review existed but was not discussed in the opinion. California Oil Co. v. Huffstutler, 322 F.2d 596 (5th Cir. 1963). Huffstutler was an oil drilling-permit case nearly identical to Burford and involved a similar centralized system of judicial review, see LA. Rev. Stat. ANN. $\S 30: 12$ (West 1975). The case was complicated, however, by the bankruptcy of the permittee. The Fifth Circuit treated the case mainly as a problem of bankruptcy law, with Burford cited as a policy argument rather than as a controlling doctrine. 
cases, appeal went directly to the state supreme courts. ${ }^{77}$ In another case, the state had established special procedural and venue rules and a careful distribution of jurisdiction among the state courts. ${ }^{78}$ In a third, the exclusive means of judicial review was a particular form of action and remedy, a statutory action similar to mandamus. ${ }^{79}$ Even though the case involved claims arising under the Federal Constitution, the court abstained in order to avoid contravening the state's procedural policy. ${ }^{80}$

4. State Regulatory Agencies. Both Burford and Alabama $P S C$ involved orders of state regulatory agencies. A few lower courts have abstained in cases that, although involving state regulation, were based on statutory causes of action rather than on challenges to administrative orders. ${ }^{81}$ Other courts have abstained in suits challenging administrative actions that did not concern regulated activities. ${ }^{82}$ Yet courts have usually refused, because of the absence of a comprehensive statewide regulatory scheme, to abstain in suits challenging student-discipline policies of public high schools. ${ }^{83}$ Courts have also refused to abstain in cases dealing with such institutions as state prisons and universities on the ground that these institutions are not subject to complicated state regulatory schemes. ${ }^{84}$

7 Allstate Ins. Co. v. Sabbagh, 603 F.2d 228, 233 (1st Cir. 1979); Construction Aggregates Corp. v. Rivera de Vincenty, 573 F.2d 86, 96 (1st Cir. 1978) (refusing abstention on other issues). In Allstate, the First Circuit emphasized that the state court had available a broader range of nonintrusive remedial devices. $603 \mathrm{~F} .2 \mathrm{~d}$ at 233 .

${ }^{78}$ Ali v. Division of State Athletic Comm'n, 308 F. Supp. 11, 19 (S.D.N.Y. 1969) (dictum), relief granted on new pleadings, 316 F. Supp. 1246 (S.D.N.Y. 1970).

" Cobb v. City of Malden, 202 F.2d 701 (1st Cir. 1953).

so Id. at 704. See also text and notes at notes 141-143 infra.

81 Brown v. First Nat'l City Bank, 503 F.2d 114 (2d Cir. 1974) (dictum); AFA Distrib. Co. v. Pearl Brewing Co., 470 F. 2d 1210 (4th Cir. 1973) (alternative ground for abstention). Cf. Barrett v. Atlantic Richfield Co., 444 F.2d 38 (5th Cir. 1971) (administrative orders only tangentially involved).

${ }_{82}$ Garrett v. Bamford, 582 F.2d 810, 819 (3d Cir. 1978) (taxpayers challenged county property assessment method as racially discriminatory); Gray-Taylor, Inc. v. Harris County, 569 F.2d 893 (5th Cir. 1978) (per curiam) (same); Simmons v. Jones, 478 F.2d 321, 327-28 (5th Cir. 1973) (jury-pool selection), modified per curiam, 519 F.2d 52 (5th Cir. 1975); Cobb v. City of Malden, 202 F.2d 701 (1st Cir. 1953) (local school funding).

\& Canton v. Spokane School Dist. \#81, 498 F.2d 840, 843-46 (9th Cir. 1974); Garvin v. Rosenau, 455 F.2d 233, 239 (6th Cir. 1972); Karr v. Schmidt, 320 F. Supp. 728, 730 (W.D. Tex. 1970), rev'd on the merits, 460 F.2d 609 (5th Cir.) (en banc), cert. denied, 409 U.S. 989 (1972). See Hobbs v. Thompson, 448 F.2d 456, 461 n.11 (5th Cir. 1971) (rejecting district court abstentions); Moreno v. Henckel, 431 F.2d 1299, 1303 n.9 (5th Cir. 1970); Hall v. Garson, 430 F.2d 430, 436-37 (5th Cir. 1970) (same).

st Campbell v. McGruder, 580 F.2d 521, 525 (D.C. Cir. 1978); Moreno v. University of Md., 420 F. Supp. 541, 552 (D. Md. 1976), aff'd sub nom. Moreno v. Elkins, 556 F.2d 573 (4th Cir.), question certified to state court, 435 U.S. 647 (1977), remanded sub nom. Toll v. 
5. Regulation by Local Governments. Burford and Alabama $P S C$ both involved statewide regulatory schemes mandated by the state legislatures. Some courts, however, have abstained in cases concerning local rather than statewide regulation. ${ }^{85}$ Disagreement over this application of Burford has arisen primarily in zoning and land-use cases. Some courts ordering abstention have cited the local importance of land-use policies, the local knowledge and expertise required, and the existence of established policy patterns. ${ }^{86}$ One court abstained because of the potential disruption of numerous similar local plans established to comply with goals established by the state ${ }^{87}$ But other courts have found Burford abstention improper in such cases because there was neither an integrated state policy nor any unified statewide mechanism for administrative or judicial decisionmaking. ${ }^{88}$

6. Adequacy of the State Remedy. In both Burford and Alabama PSC, the Supreme Court was careful to note that the state courts could adequately dispose of the issues, while preserving any issues of federal concern for ultimate review in the United States Supreme Court. ${ }^{8 \theta}$ The lower courts have consistently required an

Moreno, 99 S. Ct. 2044 (1979); Clutchette v. Procunier, 328 F. Supp. 767, 772 (N.D. Cal. 1971), modified and aff'd, 497 F.2d 809 (9th Cir. 1974); Carothers v. Follette, 314 F. Supp. 1014, 1019-20 (S.D.N.Y. 1970). Contra, Urbano v. Board of Managers, 415 F.2d 247 (3d Cir. 1969) (unclear state policy on prison welfare fund), cert. denied, 397 U.S. 948 (1970). The courts refusing abstention also mentioned the lack of specialized procedures for judicial review.

\&s City of Monroe v. United Gas Corp., 253 F.2d 377 (5th Cir. 1958); General Inv. \& Serv. Corp. v. Wichita Water Co., 236 F.2d 464 (10th Cir. 1956) (alternative holding). See also Cristina v. Department of State, 417 F. Supp. 1012 (S.D.N.Y. 1976) (conflict between state and city regulations); Wreiole v. Waterfront Comm'n, 132 F. Supp. 166 (S.D.N.Y. 1955) (local multistate agency); Applegate v. Waterfront Comm'n, 129 F. Supp. 71 (S.D.N.Y. 1955) (same).

${ }^{85}$ Gregg v, Winchester, 173 F.2d 512, 515 (9th Cir.) (dictum), cert. denied, 338 U.S. 847 (1949); Kent Island Joint Venture v. Smith, 452 F. Supp. 455, 461-63 (D. Md. 1978); Stallworth v. City of Monroeville, 426 F. Supp. 236, 240 (S.D. Ala. 1976); Harris v. Connecticut Light \& Power Co., 125 F. Supp. 395 (D. Conn. 1954), aff'd per curiam, 221 F.2d 958 (2d Cir. 1955).

${ }_{87}$ Santa Fe Land Improvement Co. v. City of Chula Vista, 71 F.R.D. 573 (S.D. Cal. 1976), rev'd in relevant part, 596 F.2d 838 (9th Cir. 1979). See note 133 infra.

${ }_{88}$ Santa Fe Land Improvement Co. v. City of Chula Vista, 596 F.2d 838, 841-42 (9th Cir. 1979); Rancho Palos Verdes Corp. v. City of Laguna Beach, 547 F.2d 1092, 1096 (9th Cir. 1976); Barbaccia v. County of Santa Clara, 451 F. Supp. 260, 264 (N.D. Cal. 1978); Rasmussen v. City of Lake Forest, 404 F. Supp. 148, 152-54 (N.D. Ill. 1975); Steel Hill Dev., Inc. v. Town of Sanbornton, 335 F. Supp. 947, 951-52 (D.N.H. 1971); Lerner v. Town of Islip, 272 F. Supp. 664, 667-68 (E.D.N.Y. 1967).

${ }^{89} 319$ U.S. at $334 ; 341$ U.S. at 349 . These references to the adequacy of the state court remedy, however, concerned only the legal authority and functional ability of a state court to grant relief as effective as that sought in federal court. The Supreme Court does not appear to have considered in this context the question whether a state court can serve as well as a federal court to protect out-of-state litigants or litigants asserting federal rights. See text and notes at notes $115-130$ infra. 
adequate remedy in the state courts, and several cases have cited the lack of an adequate remedy in the state courts as a ground for denying abstention. In one case, federal courts had exclusive jurisdiction over the particular area of regulation..$^{90}$ In another, an injunction was necessary for adequate judicial relief, and the state courts lacked authority to issue the injunction..$^{91}$ In a third case, the state remedy contemplated that a state agency would represent the aggrieved party in state court; the federal court concluded that adequate representation was unlikely in view of the state's hostile intervention in the federal suit. ${ }^{22}$ Another court, after noting conflicting state interpretations as to the availability of a remedy in state court, decided to proceed because the delay caused by abstention would probably put the plaintiff out of business. ${ }^{93}$ Expiration of the time for an appeal in state court during the pendency of the federal suit, however, has not been held to render the state court remedy inadequate. ${ }^{94}$

7. State-Law Claims. In McNeese v. Board of Education, ${ }^{95}$ the Supreme Court refused to abstain in a school desegregation case because the suit presented no issue of state law. The decision was inconsistent with Alabama PSC, which presented only a claim based on the due process clause of the Federal Constitution. ${ }^{96}$ The Supreme Court has never explained the inconsistency. Some courts have relied on absence of a controlling issue of state law to deny abstention. Several have reasoned that the predominance of federal law in any area means that the federal court would not intrude on any policy that is primarily within the state's concern..$^{97}$ Others have concluded that the absence of a controlling issue of state law

'0 Imperial Supply Co. v. Northern Ohio Bank, 430 F. Supp. 339, 367 (N.D. Ohio 1976) (alternative ground).

" Rivera v. Chapel, 366 F. Supp. 691, 697 (D.P.R. 1973) (alternative ground), vacated on other grounds, 493 F.2d 1302 (1st Cir. 1974).

22 Baltimore Bank for Coops. v. Farmers Cheese Coop., 583 F.2d 104, 112 (3d Cir. 1978) (alternative ground).

${ }^{3}$ Burack v. State Liquor Auth., 160 F. Supp. 161, 164-65 (E.D.N.Y. 1958).

" Allstate Ins. Co. v. Sabbagh, 603 F.2d 228, 234 (1st Cir. 1979); Surowitz v. New York City Employees' Retirement Sys., 376 F. Supp. 369, 377 (S.D.N.Y. 1974); Allegheny Airlines, Inc. v. Pennsylvania Pub. Util. Comm'n, 319 F. Supp. 407, 413-14 (E.D. Pa. 1970), aff'd, 465 F.2d 237 (3d Cir. 1972), cert. denied, 410 U.S. 943 (1973); General Tel. Co. v. Robinson, 132 F.Supp. 39, 46 (E.D. Ark. 1955) (alternative holding) (also noting availability of renewed administrative application).

93 373 U.S. 668 (1963).

" See text and note at note 33 supra.

17 Local 519, Amalgamated Transit Union v. LaCrosse Mun. Transit Util., 585 F.2d 1340, 1350 (7th Cir. 1978); Construction Aggregates Corp. v. Rivera de Vicenty, 573 F.2d 86, 93 (1st Cir. 1978); Ktsanes v. Underwood, 467 F. Supp. 1002 (N.D. Ill. 1979); Show-World Center, Inc. v. Walsh, 438 F. Supp. 642, 650-51 (S.D.N.Y. 1977); Santiago v. City of Philadelphia, 
means that the state courts have no special expertise in the particular matter. ${ }^{98} \mathrm{~A}$ greater number of courts, however, have ignored the issue and approved abstention in cases that present no claims arising under state law. ${ }^{99}$

8. Abstention Defined Broadly. Finally, some lower courts, in ordering abstention, have not addressed any of the above considerations except the adequacy of review in the state courts. ${ }^{100}$ The authority cited in all of these cases is the broad view of abstention expressed by Chief Justice Vinson in Alabama PSC: a federal court generally should abstain in any case presenting a matter primarily of concern to state or local authorities. ${ }^{101}$

435 F. Supp. 136, 145 (E.D. Pa. 1977); United Air Lines, Inc. v. Public Utils. Comm'n, 109 F. Supp. 13, 16 (N.D. Cal. 1952), rev'd on other grounds, 346 U.S. 402 (1953); Pennsylvania Greyhound Lines v. Board of Pub. Util. Comm'rs, 107 F. Supp. 521 (D.N.J. 1952). Contra, Allstate Ins. Co. v. Sabbagh, 603 F.2d 228, 232-33 (1st Cir. 1979).

In Mobil Oil Corp. v. Kelley, 426 F. Supp. 230 (S.D. Ala. 1976), the court abstained because of a policy, reflected in federal law, to preserve the autonomy of the state in a certain area of regulation. The Federal Water Pollution Control Act, 33 U.S.C. $\$ \S 1341,1370$, $1371(c)(2)$ (1976), left certification of discharges to the relevant state administrative agencies and forbade any federal agency to review their certification decisions. The court concluded that Congress intended to leave matters of certification to the independent judgment of the states and, citing Burford, abstained from a suit to review a certification decision. $426 \mathrm{~F}$. Supp. at 235-36.

os Wynn v. Carey, 582 F.2d 1375, 1383 (7th Cir. 1978); BT Inv. Managers, Inc. v. Lewis, 559 F.2d 950, 954-55 (5th Cir. 1977), prob. juris. noted, $100 \mathrm{~S}$. Ct. 41 (1979); Clutchette v. Procunier, 328 F. Supp. 767, 772 (N.D. Cal. 1971), modified and aff'd, 497 F.2d 809 (9th Cir. 1974).

"2 Forest Hills Util. Co. v. City of Heath, 539 F.2d 592 (6th Cir. 1976); Tennyson v. Gas Serv. Co., 506 F.2d 1135, 1137 (10th Cir. 1974) (alternative holding); Allegheny Airlines, Inc. v. Pennsylvania Pub. Util. Comm'n, 465 F.2d 237 (3d Cir. 1972), cert. denied, 410 U.S. 943 (1973); Cobb v. City of Malden, 202 F.2d 701, 704 (1st Cir. 1953); Stallworth v. City of Monroeville, 426 F. Supp. 236, 240 (S.D. Ala. 1976); Zucker v. Bell Tel. Co,, 373 F. Supp. 748, 756 (E.D. Pa. 1974) (alternative holding), aff'd mem., 510 F.2d 971 (3d Cir.), cert. denied, 422 U.S. 1027 (1975); Meicler v. Aetna Cas. \& Sur. Co., 372 F. Supp. 509, 515 (S.D. Tex. 1974), aff'd on other grounds, 506 F.2d 732 (5th Cir. 1975); Mountain States Tel. \& Tel. Co. v. Public Utils. Comm'n, 345 F. Supp. 80, $86-88$ (D. Colo. 1972) (alternative holding); Pervis v. LaMarque Independent School Dist., 328 F. Supp. 638 (S.D. Tex. 1971), rev'd on other grounds, 466 F.2d 1054 (1972); Schwartz v. Galveston Independent School Dist., 309 F. Supp. 1034, 1045-46, 1048-49 (S.D. Tex. 1970) (alternative holdings); Ali v. Division of State Athletic Comm'n, 308 F. Supp. 11 (S.D.N.Y. 1969) (dictum), relief granted on new pleadings, 316 F. Supp. 1246 (S.D.N.Y. 1970); General Tel. Co. v. Robinson, 132 F. Supp. 39, 46 (E.D. Ark. 1955) (alternative holding); Walgreen Co. v. Taylor, 127 F. Supp. 657 (D. Minn.), mandamus 'denied sub nom. Walgreen Co. v. Donovan, 227 F.2d 165 (8th Cir. 1955); Gulf, M. \& O.R.R. v. Louisiana Pub. Serv. Comm'n, 120 F. Supp. 250 (E.D. La. 1954); Bowers v. Calkins, 84 F. Supp. 272 (D.N.H. 1949).

${ }^{100}$ Kelly Servs., Inc. v. Johnson, 542 F.2d 31 (7th Cir. 1976); General Inv. \& Serv. Corp. v. Wichita Water Co., 236 F.2d 464 (10th Cir. 1956); Meicler v. Aetna Cas. \& Sur. Co., 372 F. Supp. 509 (S.D. Tex. 1974), aff'd on other grounds, 506 F.2d 732 (5th Cir. 1975); Alwin Constr. Co. v. Lufkin, 360 F. Supp. 1119 (D. Conn. 1973); Wreiole v. Waterfront Comm'n, 132 F. Supp. 166 (S.D.N.Y. 1955); Applegate v. Waterfront Comm'n, 129 F. Supp. 71 (S.D.N.Y. 1955).

${ }^{101}$ See text and notes at notes $41-42$ supra. 


\section{Restriking the Equitable Balance}

Since the federal courts have failed to reach a consensus on the circumstances in which Burford abstention is proper, a reconsideration of the Burford doctrine appears necessary. To this end, the following analysis identifies the doctrinal underpinnings of Burford abstention and the limitations they imply, and in that light, reviews the elements over which the Burford cases have disagreed.

\section{A. Burford as a Form of Equitable Abstention}

In Burford, the Supreme Court relied on the concept of equitable abstention that it had elucidated in Railroad Commission $v$. Pullman Co., ${ }^{102}$ the concept that allows a court of equity to deny access to a federal court when necessary to avoid some "needless friction" in federal-state relations. The propriety of equitable abstention in Burford, however, was challenged from the outset. Justice Frankfurter, who spoke for the Court in Pullman, wrote a strongly worded dissent in Burford in which he argued that the congressional grant of diversity jurisdiction, the basis of the suit in Burford, ${ }^{103}$ foreclosed the exercise of equitable discretion to abstain. In his view, Congress had already weighed the advantages of a federal forum against the interest in state independence and determined that the neutral federal forum was needed to adjudicate the rights of out-of-state litigants. Thus, according to Justice Frankfurter, a federal court's decision to abstain because of a state's special interest in the matter being litigated would constitute a total disregard for the legislative determination embodied in the jurisdictional grant. ${ }^{104}$ In a separate opinion in Alabama PSC, he made a

102312 U.S. 496 (1941).

${ }^{103} 319$ U.S. at 317. See note 6 supra.

101319 U.S. at 336-48 (Frankfurter, J., dissenting). Three other Justices joined or concurred in the opinion, note 31 supra. In addition to making the point described in the text, Justice Frankfurter argued that the Texas legislature had not manifested an intent to confine review of the Railroad Commission's orders to the state courts of Travis County, and that the Texas courts undertook no special duties that were beyond the competence of the federal courts. Id. at 339-44. Burford was distinguishable from Pullman, according to Justice Frankfurter, since in Pullman a state court resolution of the issue of state law could moot the need for a decision on the constitutional question; that could not occur in Burford. Justice Frankfurter stated that Pullman abstention "was an affirmation and not a denial of federal jurisdiction." Id. at 338. The only basis of jurisdiction in Pullman was the federal question raised by the constitutional challenge; the question of state law was merely ancillary. Thus, a particular ruling by the state courts on the state-law claim might avoid the need to reach the federal question and thereby "terminate" the grounds for jurisdiction. Id. The principle put forward in the Burford dissent would, however, rule out Pullman abstention in any case in which diversity existed as an independent source of jurisdiction. 
similar argument based on the grant of jurisdiction in suits arising under the Constitution or federal law. ${ }^{105}$

Despite the Burford Court's failure to answer Justice Frankfurter's criticism of equitable abstention, the jurisdictional grants should not be accorded the conclusive effects he attributed to them. When Congress enacted the jurisdictional statutes, it did not purport to create a wholly new jurisprudence for the federal courts; rather, it legislated against the background of established AngloAmerican legal and equitable tradition, as it had developed and would continue to develop. That body of law continues to govern the manner in which federal courts exercise the jurisdiction granted them. Justice Frankfurter objected to Burford abstention as the use of equity to repeal selectively the jurisdictional statutes, but his own approach amounts to reading those statutes as abolishing the wellestablished doctrine of equitable discretion, which is frequently invoked to support policies of federalism and comity. ${ }^{106}$ There is no

Justice Frankfurter apparently abandoned this distinction, and his Burford dissent, in his opinion for the Court in Louisiana Power \& Light Co. v. City of Thibodaux, 360 U.S. 25 (1959), discussed in note 43 supra. The sole issue in Thibodaux was a question of state law, brought before the federal courts by way of diversity jurisdiction; the purpose of abstention was to allow that issue to be resolved by the state courts. Justice Frankfurter ordered the district court to retain jurisdiction "should anything prevent a prompt state court determination," 360 U.S. at 31 , but he was apparently aware of the fact that, unless something went wrong unexpectedly, the state disposition would leave no issue for the federal court to resolve. See note 113 infra. Thus, Thibodaux is incompatible with Justice Frankfurter's principle that federal courts may not shirk an issue properly put before them by a jurisdictional statute.

${ }^{105} 341$ U.S. at 351-62 (Frankfurter, J., concurring in the result). See note 33 supra. Justice Frankfurter, joined by Justice Jackson, concurred in the result, concluding that Southern Railway's due process claim was without merit. Justice Frankfurter appears at this point to have accepted the Burford decision as representing an example "of special circum. stances which make it desirable for the court to stay its hand," $i d$. at 360 , but disagreed with Chief Justice Vinson's extension of Burford beyond its facts.

${ }^{108}$ Equitable discretion was so used in Pullman, in which Justice Frankfurter wrote the opinion of the Court. See text and notes at notes 11-16 supra. See also Pennsylvania v. Williams, 294 U.S. 176 (1935); Hawks v. Hamill, 288 U.S. 52, 60-61 (1933) (alternative holding); Cavanaugh v. Looney, 248 U.S. 453, 456 (1919); Ex parte Young, 209 U.S. 123, 16667 (1908).

An unresolved problem is whether abstention, equitable in its origins and theory, is entirely limited to cases seeking equitable relief. In Louisiana Power \& Light Co. v. City of Thibodaux, 360 U.S. 25 (1959), the Supreme Court approved abstention in an eminent domain action. Justice Frankfurter, writing for the Court, remarked that prior abstention cases, though in equity, "did not apply a technical rule of equity procedure," id. at 28 . Although eminent domain technically falls under the heading of law, "it is of a special and peculiar nature." Id. See note 43 supra. Cf. Great Lakes Dock \& Dredge Co. v. Huffman, 319 U.S. 293, 297-300 (1943) (abstention proper in declaratory judgment action because discretion exercised in such suits is similar to equitable discretion).

Thibodaux has led some to conclude that abstention is available without regard to whether a case is legal or equitable, e.g., Beach v. Rome Trust Co., 269 F.2d 367, 373-74 (2d 
authority suggesting any such innovative intent on Congress's part; on the contrary, Burford has survived thirty-six years of congressional activity, including the complete recodification of the judicial code in $1948,{ }^{107}$ without any serious challenge to this supposed usurpation of Congress's prerogative. It is sounder to characterize abstention as Justice Frankfurter himself did in Pullman: "This use of equitable powers is a contribution of the courts in furthering the harmonious relation between state and federal authority without the need for rigorous congressional restriction of those powers."

Whatever the merits of these arguments, it is clear that the equitable foundation of abstention is firmly established as far as the courts are concerned. Not only has Burford abstention survived for over three decades, but Supreme Court decisions finding abstention

Cir. 1959). The more common view, however, is that Thibodaux created only a very limited exception based on the special equity-like nature of eminent domain, and that abstention is otherwise limited to equity cases. E.g., Baltimore Bank for Coops. v. Farmers Cheese Coop., 583 F.2d 104, 111-12 (3d Cir. 1978); Clark v. Lutcher, 436 F. Supp. 1266, 1271-72 (M.D. Pa. 1977). See also Cobb v. City of Malden, 202 F.2d 701, 704-05 (1st Cir. 1953). See generally Comment, The Tax Injunction Act and Suits for Monetary Relief, 46 U. CHI. L. REv. 736, 762 n.136 (1979).

Not long after Thibodaux, the Supreme Court referred to Pullman abstention in a legal action seeking damages, and sent a state-law question to state court under Florida's certification procedure. Clay v. Sun Ins. Office Ltd., 363 U.S. 207 (1960). The decision might simply be an anomaly, since the Court did not advert at all to the law-equity issue. Since it involved a certification rather than an instance of straightforward abstention, it is perhaps better to tie the case to a court's general discretionary control over its own docket, a power unrelated to the equitable or legal nature of a suit. Indeed, Professor Moore suggests that this is an alternative foundation for all Pullman abstention, IA J. Moone, supra note 1, II 0-.203[1], at 2105. There appears to be no case law adopting this explanation.

Abstention is said to be founded on "equitable discretion," but in fact that discretion exists more in jurisprudential theory than in courtroom reality. Appellate courts review abstention decisions with much the same rigor given to applications of statutes. 1A J. Moore, supra note 1, 70.203 [1], at 2105-06. See Louisiana Power \& Light Co. v. City of Thibodaux, 360 U.S. 25, 28 (1959); Penagaricano v. Allen Corp., 267 F.2d 550, 558 (1st Cir. 1959).

107 Pub. L. No. 80-773, 62 Stat. 869 (1948). In 1969, the American Law Institute proposed to codify the abstention doctrine as a part of its general revision of the federal jurisdictional statutes. American Law Institute, Study of the Division of JuRisdiction Between State and FEDERal CourTs 48-49, 282-98 (1969) (proposed $\$ 1371(\mathrm{c})$ ). Congress has considered adopting the ALI's proposed reform, but no major action has been taken. See S. REP. No. 67, 93d Cong., 1st Sess. 8-9, 15 (1973); S. ReP. No. 893, 92d Cong., 2d Sess. 9-11, 14 (1972). The abstention feature of the proposed bill, S. 1876, 92d Cong., 1st \& 2d Sess. (1972), appears to have aroused little controversy; the main dispute on the point seems to have been whether it would be better to codify abstention or to leave it in its present judge-made status. Compare Hearings on S. 1876 Before the Subcomm. on Improvements in Judicial Machinery of the Senate Comm. on the Judiciary, 92d Cong., 2d Sess. 765-66, 772-82 (1972) (statement of Charles Alan Wright) with id. at 759-60 (statement of Judge Henry J. Friendly). See also Currie, The Federal Courts and the American Law Institute (pt. 2), 36 U. CHI. L. REv. 268, 311-19 (1969).

${ }^{103} 312$ U.S. at 501. See Note, Judicial Abstention from the Exercise of Federal Jurisdiction, 59 Colum. L. REv. 749, 777-78 (1959). 
unjustified have nevertheless acknowledged the legitimacy of abstention in general. ${ }^{109}$

Justice Frankfurter's criticisms are important, however, when considering the doctrinal limitations of Burford abstention. Since the doctrine constitutes a modification of an act of Congress, its application cannot properly extend beyond the range of the equitable authority that justifies it. Specifically, then, Burford abstention should be limited to those cases in which the benefit to the plaintiff of federal adjudication is outweighed by the harm that federal adjudication might cause to valid state policies and federal-state relations.

The courts are in agreement that Burford abstention is improper unless the state offers a judicial remedy that can adequately and promptly dispose of the issues in the suit and can provide effective relief. ${ }^{110}$ Furthermore, abstention has no res judicata effect; plaintiffs are free to raise any issue in state court that they could have raised in federal court. Hence, abstention has no formal substantive consequences; its sole direct result is to change the forum in which an action proceeds.

On the other hand, Burford abstention results in a complete denial of a federal forum. In this respect, it is more severe than the other major abstention doctrines. Under Pullman abstention, the federal court retains jurisdiction while the litigants proceed in state court on state-law issues. ${ }^{111}$ The plaintiff may return to federal court if the state court does not decide the state-law issues in a manner that obviates the need to resolve a federal constitutional issue; the plaintiff need only present his state-law claims to the state court while reserving his federal claims for later adjudication, if necessary, in federal court. ${ }^{112}$ Similarly, under abstention based on the authority of Louisiana Power \& Light Co. $v$. City of Thibodaux, ${ }^{113}$

${ }_{109}$ Zablocki v. Redhail, 434 U.S. 374, 379 n.5 (1978); Colorado River Water Conservation Dist. v. United States, 424 U.S. 800, 814-16 (1976); McNeese v. Board of Educ., 373 U.S. 668, 673 (1963); County of Allegheny v. Frank Mashuda Co., 360 U.S. 185, 189 (1959); Meredith v. Winter Haven, 320 U.S. 228, 234-36 (1943).

110 See text and notes at notes 89-94 supra.

11312 U.S. 496, 501-02. Accord, e.g., American Trial Lawyers Ass'n v. New Jersey Supreme Court, 409 U.S. 467, 469 (1973). But cf. Harris County Comm'rs Court v. Moore, 420 U.S. 77, 88 n.14 (1975) (dismissal proper because Texas courts lacked jurisdiction to decide cases over which the federal court retained jurisdiction). The Supreme Court has described Pullman abstention as not "[ $t]$ he abdication of federal jurisdiction, but only the postponement of its exercise." Harrison v. NAACP, 360 U.S. 167, 177 (1959). See generally 17 C. Wright, A. Minter \& E. CoOper, supra note $1, \S 4243$, at 472.

112 England v. Louisiana Bd. of Medical Examiners, 375 U.S. 411, $415-17$ (1964).

113360 U.S. 25, 30-31 (1959), discussed in note 43 supra. For a similar case, see Kaiser Steel Corp. v. W.S. Ranch Co., 391 U.S. 593, 594 (1968) (per curiam). It is unclear just what 
the federal court will retain jurisdiction in the event that the state court fails to dispose of the case promptly or issues of federal law remain after resolution of the state-law issues. But in Burford abstention, the federal court dismisses the entire case, federal and state claims alike..$^{14}$

These considerations set the parameters for an inquiry into the proper scope of Burford abstention. Both sides of the equitable balance-the public interest and the plaintiff's private right-must be weighed solely in terms of the importance of a federal forum. Hence, the public interest to be considered consists solely of avoiding the public harm that will allegedly result from federal judicial intervention. Conversely, the damage caused to the plaintiff by a decision to abstain does not implicate the importance of the substantive rights he asserts; rather, it consists solely of the prejudicial effect on those rights caused by the denial of a federal forum. This comment must therefore address two inquiries: first, which interests protected by the jurisdictional statutes are impaired when a plaintiff's case is sent to state court; and second, in which of the circumstances that have arisen under the Burford doctrine is a plaintiff's interest in a federal forum outweighed by considerations of comity and federalism.

\section{B. Denial of the Federal Forum}

While plaintiffs, or defendants seeking removal to federal court, ${ }^{115}$ may desire to litigate in federal court for a variety of rea-

function is intended to be served by retention of jurisdiction in Thibodaux cases. In neither Thibodaux nor Kaiser was there any federal question to reserve. Both opinions seem to suggest that the plaintiffs should bring declaratory judgment actions in state court, and that the federal courts could then provide whatever remedial measures might be necessary. But it is hard to see why the state court, having dispositively determined the rights of the parties, is not also the proper court to fashion the appropriate remedy. Retention also assures relief in case the state courts, through some institutional failure, do not render a prompt or thorough disposition. Thibodaux, 360 U.S. at 31. The same danger exists in Burford abstention, though; there it is handled by dismissing without prejudice to the plaintiff's right to return to federal court if state remedies prove inadequate (an approach that avoids rendering the state decision advisory). At any rate, it seems anomalous to create this putatively stronger backstop for Thibodaux abstention but to withhold it in Burford abstention, where federal claims are far more common.

11 See Santa Fe Land Improvement Co. v. City of Chula Vista, 596 F.2d 838 (9th Cir. 1979); Urbano v. Board of Managers, 415 F.2d 247, 254 (3d Cir. 1969), cert. denied, 397 U.S. 948 (1970); Kent Island Joint Venture v. Smith, 452 F. Supp. 455, 464 (D. Md. 1978); 17 C. Wright, A. MrLer \& E. Cooper, supra note 1, § 4245, at 490-91; Gowan \& Izlar, supra note 43, at 197, 199; Note, Federal-Question Abstention, 80 HARv. L. REv. 604, 604 n.7 (1967). See also Liebenthal, $A$ Dialogue on England: The England Case, Its Effect on the Abstention Doctrine, and Some Suggested Solutions, 18 W. REs. L. REv. 157, 158-66 (1966).

"15 See 28 U.S.C. \$§ 1441-1444 (1976). 
sons, the jurisdictional statutes generally seek to protect one particular interest: the interest in litigating claims in a forum free of local bias. The cases involving Burford abstention, including Burford and Alabama PSC, have typically involved allegations of a combination of grounds for federal jurisdiction, primarily diversity of citizenship, ${ }^{116}$ federal question, ${ }^{117}$ and civil rights. ${ }^{118}$ The diversity jurisdiction serves to protect out-of-state litigants from bias in state courts that might favor local opponents. ${ }^{119}$ The federal question and civil rights jurisdictions serve to protect against the possibility of state court hostility to vindication of federal rights. ${ }^{120}$ Therefore, the decision to abstain deprives the plaintiff of the protections that the jurisdictional statutes were established to provide.

The potential for state court bias in Burford abstention cases is substantial in comparison with other forms of abstention. In abstention under Pullman and Thibodaux, the federal courts abstain in order to allow the state courts to construe an unclear state law. ${ }^{121}$ A state court's prejudice against a plaintiff who is a nonresident, or who also has federal claims, could conceivably induce the court to interpret a state law differently than it otherwise might. A state court's prejudice, however, would likely be restrained by the knowledge that other litigants may be bound by the precedent. ${ }^{122}$ Moreover, since under Pullman the plaintiff may return to

116 Id. § 1332 .

117 Id. $\$ 1331$.

${ }^{118} I d$. $\S 1343(3)$.

11 See Guaranty Trust Co. v. York, 326 U.S. 99, 111 (1945); Burford, 319 U.S. at 336 (Frankfurter, J., dissenting); Erie R.R. v. Tompkins, 304 U.S. 64, 74 (1938); Pease v. Peck, 59 U.S. (18 How.) 595, 599 (1855); Martin v. Hunter's Lessee, 14 U.S. (1 Wheat.) 304, 34647 (1816); Bank of the United States v. Deveaux, 9 U.S. (5 Cranch) 61, 87 (1809). Many see the diversity jurisdiction as assuaging litigants' apprehensions of prejudice as well as protecting against actual state bias. See id.; AMERICAN LAw INSTITUTE, supra note 107, at 101. Some commentators have further suggested that an out-of-state party who seeks to bring an action in a state that has courts of inferior quality should have a right to sue in a federal court because he is not responsible for the inferior quality of that state's courts. See id.; C. WRIGHT, supra note $16, \S 23$, at 90 .

120 See Paduano v. Yamashita Kisen Kabushiki Kaisha, 221 F.2d 615, 618 (2d Cir. 1955); The Federalist No. 81 (A. Hamilton). See also Martin v. Hunter's Lessee, 14 U.S. (1 Wheat.) 304,347 (1816).

121 See text and notes at notes $11-16$ \& note 43 supra.

122 The court might not be so deterred if the issue is the construction of a state law that affects only nonresidents, such as a statute concerning foreign corporations. State court constructions of such laws, though, are absolutely binding on federal courts; the federal courts must act on the premise that the state courts are correctly interpreting the will of the legislature, no matter how egregious the state interpretations appear to an objective observer. It is open to question, therefore, whether as a jurisprudential matter the federal courts may impute any perceived antiforeign bias to the state courts, or whether they must impute it to the legislature. 
federal court for determination, if necessary, of federal claims, the state court may be further deterred from a prejudicial decision by the possibility of a federal constitutional challenge to the state law should the court decide against the plaintiff. Under the Burford doctrine, however, abstention is not limited to cases presenting difficulties in the interpretation of state law, and often no such difficulties are present. The cases in which Burford is applicable usually involve determinations of fact under state law, such as, for example, in Burford, whether a drilling permit was necessary to prevent waste or confiscation. ${ }^{123}$ Since such factual determinations are binding only on the case at hand, the state court does not encounter the same restraints against prejudicial decisions as it does when construing state law. ${ }^{124}$ Thus, in contrast to Pullman or Thibodaux abstention, in the typical case that is subject to Burford abstention there is a stronger claim for a neutral federal forum.

The extent of local prejudice in a case subject to Burford abstention also depends on the nature of the administrative action being challenged. Burford cases have tended to involve challenges to individual regulatory orders or applications of public policies in individual cases; rarely have they involved challenges to entire regulatory structures or public policy schemes. ${ }^{125}$ Consequently, Burford cases present less potential for a judge to translate his support for local policies into prejudice against a challenger. Furthermore, Burford cases have typically involved challenges to agency action based on relatively dispassionate grounds, such as violation of state regulatory standards ${ }^{128}$ or confiscatory regulation ${ }^{127}$ rather than on

12319 U.S. at 322-25. There is, of course, no reason why a Pullman or a Thibodaux abstention case might not include both a difficult interpretation of state law and a difficult factual issue. Attention has been focused here, however, on an element that distinguishes the types of abstention. See note 43 supra.

121 When a state court makes findings of fact that pertain to a federal-law claim, the Supreme Court might, in special circumstances, review those findings. The test is whether the questions of law and fact are "so intermingled" as to make separate review of the questions of law impossible. See Norris v. Alabama, 294 U.S. 587, 590 (1935); Fiske v. Kansas, 274 U.S. 380, 385-86 (1927); C. WRIGHT, supra note 16, $\S 108$, at 553. This form of review has fallen into disregard, though, except in special circumstances such as obscenity cases. In regulatory cases, the review is generally limited to assuring that the state court's findings have some support in the evidence. See Hill, The Inadequate State Ground, 65 Colum. L. REv. 943, 945-46, 947 n.18 (1965); Note, Supreme Court Review of State Findings of Fact in Fourteenth Amendment Cases, 14 Stan. L. REv. 328 (1962).

${ }^{123}$ But see Donohoe Constr. Co. v. Montgomery County Council, 567 F.2d 603, 607 n.12 (4th Cir. 1977), cert. denied, 438 U.S. 905 (1978).

${ }^{124}$ E.g., Burford v. Sun Oil Co., 319 U.S. 315 (1943); Allegheny Airlines, Inc. v. Pennsylvania Pub. Util. Comm'n, 465 F.2d 237 (3d Cir. 1972); Bowers v. Calkins, 84 F. Supp. 272 (D.N.H. 1949).

127 E.g., Alabama Pub. Serv. Comm'n v. Southern Ry., 341 U.S. 341 (1951); City of 
more divisive grounds such as racial discrimination. On the other hand, a state judge may strongly favor the enforcement of a regulatory order or public policy because of prior or current affiliation with political interests that favor the order or policy. It is also possible that individual judges may bear prejudice against utilities and other large corporations, which are often the plaintiffs in Burford cases. Thus, the susceptibility of the substantive issues in Burford cases to local prejudices is uncertain.

The plaintiff's interest in a federal forum is increased by the costs that abstention might impose on him: abstention will require the plaintiff to initiate a second law suit and consequently will entail some delay and repetition of work. ${ }^{128}$ The amount of delay and repetition will depend, of course, upon the stage of litigation at which the court orders abstention. On a few occasions, cases have progressed to completion of trial, only to have an appellate court reverse on the grounds that Burford abstention should have been ordered. ${ }^{128}$ Very few courts have addressed the problem of increased expense and delay. ${ }^{130}$ Given the nature of Burford abstention as a form of equitable abstention, however, this consideration ought properly to be taken into account in a court's decision respecting abstention.

On one side of the balance that underlies Burford abstention, therefore, is the substantial right of the plaintiff to sue in federal court. The plaintiff has an interest, recognized in the jurisdictional statutes, in gaining access to a forum free of local prejudice. In addition, he has an interest in avoiding the delay and expense caused by abstention.

\section{Harm to State Policies or Federal-State Relations}

On the other side of the equitable balance is the danger that adjudication of a particular issue in federal court will cause undue harm to legitimate state policies and federal-state relations. As we

Monroe v. United Gas Corp., 253 F.2d 377 (5th Cir. 1958); Mountain States Tel. \& Tel. Co. v. Public Utils. Comm'n, 345 F. Supp. 80 (D. Colo. 1972).

${ }^{12 s}$ This consideration does not apply where defendants are seeking removal to federal court. The delay in Burford cases will seldom match that often encountered in Pullman and Thibodaux cases. Litigants in these cases can spend years shuttling back and forth between federal and state court. See generally D. CuRRIE, supra note 1, at 654-55 (1975).

1w E.g., Alabama Pub. Serv. Comm'n v. Southern Ry., 341 U.S. 341 (1951); Kelly Servs., Inc. v. Johnson, 542 F.2d 31 (7th Cir. 1976); Simmons v. Jones, 478 F.2d 321 (5th Cir. 1973), modified per curiam, 519 F.2d 52 (5th Cir. 1975).

${ }^{130}$ The only examples discovered are Atchison, T. \& S.F. Ry. v. Illinois Commerce Comm'n, 453 F. Supp. 920, 922 (N.D. Ill. 1977); Rivera v. Chapel, 366 F. Supp. 691, 697 (D.P.R. 1973) (alternative ground), vacated on other grounds, 493 F.2d 1302 (1st Cir. 1974). 
have seen, courts have found that a variety of factors, either singly or in combination, justifies abstention. On careful analysis, however, only a limited combination of factors is sufficient to outweigh the plaintiff's recognized interest in a federal forum.

1. Disruption of State Policies. The one element that has perhaps received the most emphasis in Burford abstention cases is the possibility that a federal court will reach a result that seriously disrupts a state's development and implementation of an important public policy. ${ }^{131}$ The possibility of disruption, however, does not present a compelling case for abstention unless, as contemplated in Burford, it would be the consequence of a federal court's erroneous resolution of the issues in the case. If the federal court correctly resolves the dispute, its resolution causes no more disruption than would a state court resolution, unless the state court unduly favored the state's interest ${ }^{132}$-the very result that the federal jurisdictional grants were intended to prevent. Abstention is thus inappropriate. ${ }^{133}$

If the rationale for abstention is the avoidance of a potentially disruptive error by a federal court, abstention seems proper only where the state court is significantly less likely to make such an error. If the state is just as likely as (or more likely than) the federal court to make an error, it is difficult to see how abstention could be justified. Since it is in theory impossible that a federal court is more likely than a state court to err in the interpretation or application of federal law, Burford abstention, based on a potential-disruption rationale, must be confined to the avoidance of errors by federal courts concerning state law. ${ }^{134}$

13 See text and notes at notes 52-64 supra.

${ }^{132}$ A federal court should consider the public policies of the state when fashioning equitable relief. See notes 14, 106 supra. What is contemplated here, however, is the state court giving undue weight to the state interest.

133 Cf. Zablocki v. Redhail, 434 U.S. 374, 379 n.5 (1978) ("[T]here is, of course, no doctrine requiring abstention merely because resolution of a federal question may result in the overturning of a state policy."); Allstate Ins. Co. v. Sabbagh, 603 F.2d 228, 232 (1st Cir. 1979) (dictum) ("The state has no right to an unconstitutional policy, coherent or otherwise."). An example of improper abstention is Santa Fe Land Improvement Co. v. City of Chula Vista, 71 F.R.D. 573 (S.D. Cal. 1976), rev'd in relevant part, 596 F.2d 838 (9th Cir. 1979). The city had adopted a system of rezoning to comply with a state-mandated openspaces policy. Abstaining under the Burford doctrine, the court noted that numerous other cities had adopted similar procedures and that a finding of illegality might disrupt efforts to implement the state policy. Id. at 576. But if the cities' procedures were illegal under either federal or state law, then they deserved to be "disrupted." On appeal, the Ninth Circuit upheld Pullman abstention but reversed the dismissal because Burford abstention was inappropriate. $596 \mathrm{~F} .2 \mathrm{~d}$ at 838 .

131 This is not to say that the presence of a federal question will always negate the possibility of Burford abstention. A single case might include both a a state-law question that 
The possibility of error by a federal court, however, cannot alone be sufficient to justify Burford abstention. Erroneous application of state law is, for example, always a risk in cases decided under the Erie doctrine; ${ }^{135}$ but Congress has determined that this risk is generally outweighed by the risk of local prejudice to out-of-state plaintiffs. ${ }^{136}$ Abstention based solely on the possibility of federal court error would therefore effectively nullify federal jurisdiction based on diversity of citizenship.

Where the error will have an impact on state policy beyond the scope of the issues litigated in the particular case, however, an argument can be made for Burford abstention. The paradigmatic situation is the oil-drilling problem in Burford. ${ }^{137}$ Since production at one well affects production at other wells in the same field, an error by a federal court with regard to whether drilling should be permitted at one site would necessarily have repercussions beyond the immediate case, and could disrupt the state's overall efforts to achieve maximum recovery and fair allocation of production in the field. The potential injury to state policy in such a situation thus involves more than application of state policy to the parties involved in the litigation. Consequently, a court might reasonably find that the state's interest in avoiding disruption of this magnitude is sufficiently greater than any interest in the outcome of a particular case to require restriking the balance of interests established by the federal jurisdictional grants. But because the plaintiff's interest in vindication of his rights in a federal court is recognized by an act of Congress, it must carry substantial weight. Therefore, the right ought not to be displaced to prevent a minor

presents a threat of disruption and a federal-law question. In such a case, unless the claims could be tried separately, the federal court would have to weigh the plaintiff's right to a federal forum on the federal question as part of the balance of equities. See Colorado River Water Conservation Dist. v. United States, 424 U.S. 800, 815 n.21 (1976) ("the presence of a federal basis for jurisdiction may raise the level of justification needed for abstention").

${ }^{135}$ Erie R.R. v. Tompkins, 304 U.S. 64 (1938). See generally C. WrIGHT, supra note 16, $\S \S 55-59$.

136 See text and note at note 119 supra. Even when a federal court applies state law incorrectly, the result is not usually disruption of any state policy, but only injustice to particular litigants. Robertsen v. State Farm Mut. Auto Ins. Co., 464 F. Supp. 876, 878-79 (D.S.C. 1979). Moreover, if the reason the federal decision differs from what the state court would have decided is that the federal court found the facts differently, then the difference is sanctioned by the policies behind the grants of federal jurisdiction. Allowing a case to be brought in federal court serves no purpose unless it is assumed that the federal court may reach a more just, and therefore different, result. See Burford, 319 U.S. at 344 (Frankfurter, J., dissenting); text and notes at notes 116.127 supra.

${ }_{137}$ See text and notes at notes 17-31 supra. But see Louisiana Power \& Light Co. v. City of Thibodaux, 360 U.S. 25 (1959), discussed in note 43 supra. 
interference with state policies that are not of great public concern. ${ }^{138}$

The general rule that emerges from this analysis of the potential-disruption problem is that Burford abstention may be appropriate when necessary to avoid an error by a federal court concerning state law that would have a disruptive effect on important state policies, but only when that effect extends beyond the scope of the issues litigated in the immediate case.

2. Special Expertise. One of the factors noted in Burford as supporting abstention was the fact that the Texas courts had developed a special expertise in handling the complex problems that arise in oil-field regulation. That expertise, in the Court's view, enabled the state courts to avoid erroneous or inconsistent decisions that could disrupt the state's regulation of the oil fields. ${ }^{139}$

In light of the reasoning of the Burford Court, it seems appropriate to require a showing of state court expertise. If the purpose of abstention is to avoid the danger that the state's policies could be disrupted by inconsistent or incorrect federal decisions, then preferring a state forum to a federal one serves no purpose unless the state court is significantly less likely to commit disruptive error. Burford cases typically involve application of established legal standards to complex factual situations; hence, state courts may have greater expertise because they have become more familiar with the practical problems involved and more able to recognize the importance of previous decisions dealing with those problems.

Considered alone, however, special expertise in the state courts is not a sufficient reason for abstention. Where the effect of a possible error by a federal court would be confined to the particular case, the federal jurisdictional grants reflect a determination that the benefit of state court adjudication to the state does not outweigh the plaintiff's protected interest in federal adjudication. Not surprisingly, therefore, the Supreme Court has stated that abstention is not to be employed merely because the state courts are better able to decide certain difficult issues. ${ }^{140}$

3. Exclusive State Judicial Remedy. In both Burford and Alabama PSC, the Court, in ordering abstention, found pertinent the fact that the states had concentrated review of commission or-

138 The Supreme Court has used the phrase, "a matter of substantial public concern."

Colorado River Water Conservation Dist. v. United States, 424 U.S. 800, 814 (1976).

139 See text and notes at notes 25-31 supra.

to Meredith v. Winter Haven, 320 U.S. 228, 234 (1943). See also Colorado River Water Conservation Dist. v. United States, 424 U.S. 800, 815-16 (1976). 
ders in the courts of the capital counties. ${ }^{141}$ The concentration of judicial review, or any other special structure of judicial review, cannot alone justify abstention. A structure of judicial review might be established, for example, to suit the convenience of an administrative agency's counsel, or to achieve a desired distribution of labor among state courts. Since the existence of an exclusive judicial remedy does not by itself justify an abstention decision, ${ }^{1.12}$ the reason for establishing the exclusive judicial remedy must support the decision to abstain. If, for example, the rationale for abstention is based on potential disruption of state policy, then a special structure of judicial review may be indicative of special expertise in the state courts, of the importance of the state policy, or of the danger that parallel lines of review will result in inconsistent decisions. In contrast, the fact that a state has not established a special structure of review will likely weigh against Burford abstention. If judicial review is not concentrated, it is less likely that the state court will have special expertise in the subject of the suit or that the state interest in avoiding parallel lines of review can be demonstrated..$^{143}$ Therefore, the structure of judicial review established by the state should properly be regarded as neither a necessary nor a sufficient factor, but rather as a relevant factor in determining the likelihood of a disruptive error in federal court adjudication.

4. Concern for State Sensibilities. All of the reasons considered thus far on which courts have based abstention have related to potential disruption of state policies. Chief Justice Vinson's opinion in Alabama PSC, however, can be read to give a broader scope to Burford abstention by suggesting that abstention is the general rule in cases that review state administrative orders and present issues

14 See text and notes at notes 25,38 supra.

${ }^{142}$ But see Cobb v. City of Malden, 202 F.2d 701 (1st Cir. 1953). In Cobb, the court characterized an exclusive judicial remedy as itself a policy of sufficient importance to warrant abstention. Public school teachers had sued, alleging that a municipality's failure to appropriate sufficient funds to pay their salaries violated their federal constitutional rights. Massachusetts provided an exclusive remedy, a special form of action similar to mandamus, for actions to compel municipalities to appropriate funds necessary to satisfy teachers' salaries. See 1939 Mass. Acts ch. 294 (codified at Mass. Ans. Laws ch. 71, $\S 34$ (Michie/Law. Coop. 1969)). The court found the statutory action adequate and abstained to avoid a contravention of the state's remedial policy. 202 F.2d at 704. The court failed, however, to consider the more important question of how a federal suit in equity would affect the substantive interests of the state that led to the creation of the exclusive form of action.

${ }_{113}$ This is not necessarily true in all instances, however. If a state supreme court, for example, exercises an unusually broad scope of review over lower courts, it may be able to impose the coherence that geographical concentration would have served to foster. Likewise, there may be cases in which geography and the rules of venue serve to create a de facto concentration of a certain type of cases in the courts of a few counties. 
of predominantly local concern. ${ }^{144}$ To the extent that this rule permits abstention when no threat of disruption of state policies exists, it is not clear what interest is served by abstention. Perhaps the purpose of such a rule is to avoid offending a state's sensibilities by leaving to the state courts matters that relate closely to a state's sovereignty.

This concern for the sensibilities of states, however, is an illconsidered justification for Burford abstention. Although Chief Justice Vinson may have wished to apply the rule only in administrative cases, ${ }^{145}$ its logic cannot be so confined. A federal injunction against the enforcement of a state statute, for example, would seem to be as much an irritant to state sensibilities and as much an interference with state sovereignty as federal interference with state administrative matters. If courts consistently ordered abstention to avoid offending states' sensibilities, federal judicial protection from unconstitutional state action would become nonexistent in practice. Plainly, the scope of equitable discretion permitted under the jurisdictional statutes does not extend this far. Moreover, it is precisely in those cases in which federal "interference" would most likely occur-civil rights cases, for example-that federal protection has been deemed most necessary by Congress. ${ }^{146}$ Chief Justice Vinson's suggested rule, therefore, fails to provide a compelling case for abstention where potential disruption is not present.

5. Usurpation of State Policymaking. There is, however, a much narrower argument for abstention based on deference to state sovereignty - that presented by Justice Douglas in his concurrence in Burford. ${ }^{147}$ Justice Douglas noted the broad discretion exercised by the Texas courts in reviewing orders of the Railroad Commission and the importance of the judiciary in the development of regulatory standards. ${ }^{148} \mathrm{He}$ stated that "[i]f the federal courts undertook to sit in review, so to speak, of this administrative agency, they would in effect actively participate in the fashioning of the state's domestic policy."149 This usurpation of the state court's policymaking function presented, for Justice Douglas, the most compelling reason for abstention in the Burford case.

The scope of Justice Douglas's notion of abstention is, however,

"' See text and notes at notes $41-42$ supra.

its See Alabama Pub. Serv. Comm'n v. Southern Ry., 341 U.S. 341, 350 (1951). See also Meicler v. Aetna Cas. \& Sur. Co., 372 F. Supp. 509 (S.D. Tex. 1974), aff'd on other grounds, 506 F.2d 732 (5th Cir. 1975).

14 E.g., 28 U.S.C. $\$ 1343$ (1976).

147319 U.S. at 334-36 (Douglas, J., concurring).

us See note 27 supra.

14319 U.S. at 335 (Douglas, J., concurring). 
subject to two significant limitations. First, abstention is proper, if at all, only in cases involving claims based on state law. A federal court does not intrude on the independent sphere of state policymaking when it enforces a supervening federal constitutional or statutory provision. ${ }^{150}$ Second, in cases involving issues of state regulatory law, the discretion given to state courts may be so broad and the policymaking features so prominent that the case may simply fail to present a judicial case or controversy for the federal court to decide. Such a case would not raise an abstention issue because a federal court would lack jurisdiction as an initial matter. ${ }^{151}$ Rather, Justice Douglas appears to have contemplated the case in which state law delegates enough independent policy judgment and discretion to courts to charge them with a major responsibility in formulating policy, but not enough to deprive a federal court of jurisdiction. ${ }^{152}$

Although Justice Douglas did not explicitly state why this policymaking role of state courts should lead to abstention, his opinion hints at two reasons. First, he expressly joined ${ }^{153}$ Justice Black's opinion for the Court, which stresses the possibility of disrupting a state's public policy. Second, some of his language suggests a general deference to the independence of states in matters of their public policies ${ }^{154}$-essentially the same argument for abstention later presented by Chief Justice Vinson in Alabama PSC. ${ }^{155}$ Thus, while Justice Douglas's rationale for abstention is different in formulation from those previously discussed, it does not appear to be different in substance.

6. Limitations on Abstention: State-Law Issues, State Regulatory Agencies, and Statewide Regulation. The foregoing analysis exhausts the grounds that federal courts have considered as bases for Burford abstention and leaves only the threat of a disruption of a state's policies as a persuasive ground for abstention. There are,

150 See McNeese v. Board of Educ., 373 U.S. 668, 674 (1963).

151 Prentis v. Atlantic Coast Line, 211 U.S. 210, 229 (1908). See also Bacon v. Rutland R.R., 232 U.S. 134 (1914); HART \& WECHSLER, supra note 1, at 980-83. The Burford Court passed over the Prentis-Bacon distinction as unhelpful. 319 U.S. at 325-26.

152 The case-or-controversy requirement, U.S. ConsT. art. III, $\$ 2$, cl. 1, does not appear to impose a very strict limitation on federal court jurisdiction. The Supreme Court has upheld some very broad grants of jurisdiction. See United States v. First City Bank, 386 U.S. 361, 369-70 (1967).

133319 U.S. at 334 (Douglas, J., concurring).

ist "This decision is but an application of the principle . . . that 'federal courts of equity should exercise their discretionary power with proper regard for the rightful independence of state governments in carrying out their domestic policy." "Id. at 334-35 (Douglas, J., concurring) (quoting Pennsylvania v. Williams, 294 U.S. 176, 185 (1935)).

${ }^{135}$ See text and notes at notes 41-42, 144-146 supra. 
however, three further elements that arise in the case law involving specific limitations on Burford abstention. First, several courts have held that abstention is proper only for claims arising under state law. ${ }^{156}$ This limitation, as already noted, ${ }^{157}$ is a corollary of the potential-disruption rationale.

Second, several courts have held that Burford abstention is inapplicable outside of cases involving review of state regulatory agencies. ${ }^{158}$ This restriction is a probable, although not a necessary, consequence of the potential-disruption rationale. Situations in which a federal court error is likely to have a disruptive effect beyond the scope of the immediate case will probably arise only where the factual components of separate cases are interrelated (as was the interdependence of production at separate oil wells in the Burford case) $)^{159}$ or where the components of separate policy decisions are interdependent (as where a state uses a single integrated scheme to set rates and calculate returns on a variety of types of insurance coverage). ${ }^{160}$ Although these features are not necessarily found only in areas of complex regulation for which a special state agency has been established, it is difficult to imagine a case in which such interdependencies would not be largely the result of pervasive state regulation.

Third, the lower federal courts have disagreed over whether abstention is proper in cases of local as well as statewide regulation. ${ }^{161}$ As already observed, ${ }^{162}$ Burford abstention is not aimed at avoiding intrusion into a state's sovereignty, but rather at avoiding disruption of its public policies. From the standpoint of the disruption rationale, Burford abstention can apply to regulation by local government. States delegate the responsibility for many important and complex public policies to local governments (zoning, for example), and disruption of policies at the local level is no less offensive than disruption at the state level. The only apparent distinction is that disruption of a locally administered policy would generally be less extensive than disruption of a state-administered policy. The potential scope of disruption certainly ought to affect the weight that a federal court gives to the state interest in determining

\footnotetext{
154 See text and notes at notes 95-99 supra.

137 See text and note at note 134 supra.

iss See text and notes at notes $81-84$ supra.

155 See text and notes at notes 19-23 supra.

160 See, e.g., Allstate Ins. Co. v. Sabbagh, 603 F.2d 228, 232 n.4 (1st Cir. 1979) (dictum).

ist See text and notes at notes 85-88 supra.

162 See text and notes at notes 144-146 supra.
} 
whether to abstain. It does not follow, however, that a court should never abstain in a case involving regulation by local government. ${ }^{163}$

\section{The Proper Scope of the Burford Doctrine}

The foregoing analysis demonstrates that the circumstances under which Burford abstention is appropriate are very limited. Abstention is based on the equitable principle that the public interest and the needs of federalism may sometimes justify depriving a litigant of a federal forum $;^{164}$ but most of the grounds for abstention advanced by the lower courts, when examined carefully, do not involve any benefit to state policy or federal-state relations sufficient to outweigh a plaintiff's claim to the protection of the federal courts. ${ }^{165}$ The only rationale that can justify abstention is the possibility that an erroneous federal decision could threaten a state regulatory scheme or other important state policies with serious disruption extending beyond the scope of the issues and parties in that litigation. ${ }^{186}$ Such a rationale assumes that the state court has superior expertise in applying state law to particular factual situations, and this expertise is greatly enhanced when the state has established a regulatory agency and a special judicial scheme with which to review administrative decisions. ${ }^{167}$

Moreover, since the state's interest in avoiding disruption of its public policies constitutes only one side of the equitable balance, Burford abstention might still be inappropriate, despite the possible disruptive effect of federal adjudication, in cases where the plaintiff's interest in a federal forum is unusually strong. Thus, the adequacy of the state remedy must be taken into account in evaluating the plaintiff's protected interest in litigating in a federal forum; where the state remedy is inadequate, Burford abstention will almost never be appropriate. ${ }^{168}$

The narrow formulation expounded by this comment is contrary to a fair number of the decided cases. In stressing a requirement of potential disruption, it is in conflict with a majority of the

is A statutory analog to Burford abstention is the Johnson Act, 28 U.S.C. $\$ 1342$ (1976), which restrains the federal courts from interfering with state rate-making bodies, and which applies to local as well as state-wide rate-making authorities. General Inv. \& Serv. Corp.v. Wichita Water Co., 236 F.2d 464, 466-67 (10th Cir. 1956) (alternative holding); East Ohio Gas Co. v. City of Cleveland, 94 F.2d 443, 444 (6th Cir.), cert. denied, 303 U.S. 657 (1938).

is See text and notes at notes 14-16, 106-108 supra.

1es See text and notes at notes 140,142, 144-155 supra.

166 See text and notes at notes 131-138 supra.

107 See text and notes at notes 139-143 supra.

183 See text and notes at notes 89-94 supra. 
cases in which Burford abstention has been ordered. ${ }^{169}$ Indeed, the formulation is flatly contrary to the Supreme Court's abstention decision in Alabama PSC, a case that presented no state-law claim or apparent potential for disruption, and the resolution of which required no special judicial expertise. ${ }^{170}$

On the other hand, the Supreme Court's recent opinion in Colorado River Water Conservation District v. United States ${ }^{171}$ supports the argument that potential disruption is the primary-probably the only-ground for Burford abstention. In canvassing the various categories of federal abstention, the Court described Burford abstention as appropriate where "the exercise of federal review of the question in a case and in similar cases would be disruptive of state efforts to establish a coherent policy with respect to a matter of substantial public concern."172 Although the Court did not explicitly state that no other basis for Burford abstention is proper, its failure to advance any other rationale is significant. 173 And since "[t]he facts of Alabama Public Service Commission would hardly meet Colorado's disruptive effect test,"174 Colorado River seems to represent an overruling of Alabama PSC sub silentio.

\section{CONCLUSION}

The existing case law on Burford abstention is confused and contradictory. It is often difficult to draw conclusions based on precedent about the circumstances under which abstention is proper. Nevertheless, an analysis of the policies underlying Burford reveals-and recent Supreme Court statements confirm-that abstention can be justified only when federal adjudication threatens to cause substantial disruption to state policies beyond the scope of the litigation.

If this is indeed the Supreme Court's current conception of the Burford doctrine, a more explicit statement by the Court would provide much-needed guidance to lower courts. At present,

is See text and notes at notes 53-55, 100-101 supra.

170 See text at notes 36.40 supra.

17424 U.S. 800 (1976). See text and notes at notes $47-51$ supra.

172424 U.S. at 814. See id. at 815: "[Federal review in Burford] would have had an impermissibly disruptive effect on state policy . . . ."Accord, Zablocki v. Redhail, 434 U.S. 374, 379 n.5 (1978); Zwickler v. Koota, 389 U.S. 241, 249 n.11 (1967) (dictum).

173 The Court held Burford abstention inapplicable to the case at hand because a decision would not "impair efforts to implement state policy as in Burford," 424 U.S. at 815; it did not consider any other possible argument for Burford abstention.

174 $1 \mathrm{~A} \mathrm{~J}$. Moore, supra note $1, \uparrow 0.203[2]$, at 2130.1 (footnote omitted). 
Alabama PSC and its progeny have been left, in Justice Frankfurter's words, "as derelicts on the waters of the law."175 Yet there is no reason to expect the Court to provide such guidance. Although Colorado River does not present an unmistakable command to the lower courts, it will be sufficient authority for any future restrictive Burford decisions by the Supreme Court. ${ }^{176}$ In short, although the Colorado River decision has probably decreased the incidence of unjustified applications of Burford abstention, the doctrine will continue to be a confused and cryptic corner in the law of federal jurisdiction.

Charles S. Treat

175 Alabama Pub. Serv. Comm'n v. Southern Ry., 341 U.S. 341, 357 (1951) (Frankfurter, J., concurring in the result), Cf. cases cited note 54 supra (post-Colorado River decisions in disregard of its restrictive rule).

${ }_{176}$ The case has already been used once in that fashion. Zablocki v. Redhail, 434 U.S. 374,379 n.5 (1978). 